Article

\title{
Simultaneous Stripping of Ammonia from Leachate: Experimental Insights and Key Microbial Players
}

\author{
Łukasz Jurczyk ${ }^{1, *}$, Justyna Koc-Jurczyk ${ }^{1}$ and Adam Masłoń ${ }^{2}$ (D) \\ 1 Institute of Agricultural Sciences, Land Management and Environmental Protection, University of Rzeszow, \\ str. Cwiklinskiej 1, 35-601 Rzeszów, Poland; jjurczyk@ur.edu.pl \\ 2 Faculty of Civil and Environmental Engineering and Architecture, Rzeszów University of Technology, \\ str. Poznańska 2, 35-084 Rzeszów, Poland; amaslon@prz.edu.pl \\ * Correspondence: ljurczyk@ur.edu.pl
}

Received: 22 July 2020; Accepted: 31 August 2020; Published: 7 September 2020

\begin{abstract}
Air stripping is commonly used to remove the ammonia in multistage treatment systems for municipal landfill leachate (LFL). This paper proposes a novel approach combining the process of stripping with biological removal of ammonia, based on simultaneous nitrification and denitrification (SND) in a single hybrid sequencing batch reactor (HSBR). To avoid the accumulation of free ammonia (N-FAN), the shallow aeration system was used for the treatment of raw LFL with N-TAN level of $1520 \mathrm{mg} / \mathrm{L}$ and $\mathrm{pH} 9.24$. The mean N-FAN removal efficiency of $69 \%$ with the reaction rate of $55 \mathrm{mg} \mathrm{L}^{-1} \mathrm{~h}^{-1}$ and mean ammonium $\left(\mathrm{N}^{-N_{4}}{ }_{4}^{+}\right)$removal efficiency of $84 \%$ with the reaction rate of $44 \mathrm{mg} \mathrm{L}^{-1} \mathrm{~h}^{-1}$ were achieved within a month in such an HSBR (R1). The comparative HSBR (R2), with conventional aeration system maintaining the same concentration of dissolved oxygen $\left(\mathrm{DO} \leq 1 \mathrm{mg} / \mathrm{L}\right.$ ), was removing only trace amounts of N-FAN and $48 \%$ of $\mathrm{N}^{-\mathrm{NH}_{4}}{ }^{+}$. The quantitative analysis of $16 \mathrm{~S}$ rRNA genes indicated that the number of total bacteria, Actinobacteria, Bacteroidetes, Firmicutes, and Beta- and Gammaproteobacteria increased during the operation of both HSBRs, but was always higher in R1. Moreover, the bacterial community shift was observed since the beginning of the experiment; the relative abundance of Firmicutes, and Beta- and Gammaproteobacteria increased by 5.01, 3.25 and 9.67\% respectively, whilst the abundance of Bacteroidetes and Actinobacteria decreased by 15.59 and $0.95 \%$. All of the surveyed bacteria groups, except Gammaproteobacteria, correlated significantly negatively $(p<0.001)$ with the concentrations of $\mathrm{N}^{-\mathrm{NH}_{4}}{ }^{+}$in the outflows from R1. The results allow us to suppose that simultaneous stripping and SND in a single reactor could be a promising, cost-effective and easy-to-operate solution for LFL treatment.
\end{abstract}

Keywords: aeration; ammonia stripping; hybrid SBR; microbial quantitative dynamics; municipal landfill leachate; qPCR; simultaneous nitrification and denitrification

\section{Introduction}

Despite the numerous solutions proposed in modern waste management models to reduce the mass of dumped municipal solid waste, landfilling is still a common method of disposal in many countries. Even those landfills which were properly designed and equipped with systems for monitoring and preventing the emissions are a potential source of environmental hazards, among which the most serious is the landfill leachate (LFL) [1-3]. This highly polluted liquid is produced in the process of water percolation through the waste pile, and leaches on its way products of physiochemical and biological reactions occurring in compressed layers of organic and inorganic materials. Water derives mainly from atmospheric precipitation, but is also contained as moisture in waste being delivered to the dumping site, or is generated de novo, as the organic matter decomposes. LFL is released outside when the liquid volume exceeds the retention capacity of the landfill, defined as the maximum volume 
of water that can be trapped in the porous material of the waste before it starts to leak [3]. The correct design of landfill lining should guarantee effective sealing against LFL penetration into the ground and, at the same time, allow drainage to the treatment system. In this point, choosing the technology of treatment seems to become complicated, since numerous solutions are proposed by researchers, including: nanofiltration; ultrafiltration or reverse osmosis [4]; radiolysis or ozonolysis [5]; chemical or electrochemical oxidation [6] also supported with ultrasounds or transition into a supercritical state [7]; chemical coagulation or electrocoagulation; flocculation and adsorption [8]; and lastly evaporation or stripping [9]. Although undoubtedly efficient in practice [10], all physical-chemical techniques demand a significant energy input, or a burden to the environment by consumption of chemical reagents and formation of secondary waste. They are therefore applicable where LFL contains a significant percentage of refractory organic compounds. Contrary to physical-chemical processes, the biological ones are much more environmentally friendly and cheaper in terms of operational costs, but in turn, are intended for LFL which is characterized by a relatively high $\mathrm{BOD}_{5} / \mathrm{COD}$ ratio (at least 0.1 ), typical for landfills in the early phases of maturation [11]. However, even if biodegradability potential is low, the biological treatment is still an economically viable solution as far as ammonia nitrogen removal is concerned [12]. Ammonium concentration significantly increases in LFL along with a decrease in COD concentration, when landfill's evolution enters the anoxic phases.

Biological methods are based on the biochemical activity of microorganisms creating flocs of activated sludge or the biofilm. This activity is maintained in specific conditions provided by various biological reactors, taking into consideration biomass management (e.g., recirculation systems or sequential operation), the use of different materials as biomass carriers, strategies of aeration and application of external organic carbon sources. In principle, the technologies of biological treatment were transferred directly from municipal wastewater treatment, but demanded a special approach to adapt bacterial ecosystems. The LFL differs from municipal wastewater among others, in that it has much higher N-TAN load and has a lower $\mathrm{BOD}_{5} / \mathrm{COD}$ ratio. However, what is even more significant, when municipal wastewater has a relatively constant composition, is that LFL is characterized by longand short-term substantial variations of all quantitative and qualitative indicators [13].

One of such key indicators is a $\mathrm{pH}$, and LFLs from different sites are characterized by wide variations, ranged from $<4$ to $>9$ [14], depending on age and operational parameters of landfill. High values of $\mathrm{pH}$ can be utilized to remove the ammonia load by the physical process of stripping. $\mathrm{N}-\mathrm{TAN}$ in water solutions, e.g., in wastewater, can be found in two forms, ammonium ions $\left(\mathrm{N}-\mathrm{NH}_{4}\right)$ and ammonia that tends to transfer into gaseous $\mathrm{NH}_{3}$ and is therefore commonly described as free ammonia (N-FAN).

Removal of N-TAN from wastewater is one of the main goals of the biological treatment process. In this process, the microbial degradation of nitrogenous compounds, being a part of the natural nitrogen cycle, is utilized in technical installations. Most modern treatment plants operate based on conventional biological nitrogen removal that consists of nitrification and denitrification [15]. The first process is an autotrophic two-step oxidation of $\mathrm{N}-\mathrm{NH}_{4}$ to $\mathrm{N}-\mathrm{NO}_{2}$ by ammonia-oxidizing bacteria (AOB that can be found mostly among the Beta and Gammaproteobacteria) and then to $\mathrm{N}^{-N_{3}}$ by nitrite-oxidizing bacteria (NOB, as Nitrobacter or Nitrospira). Some single species, such as Nitrospira, also shows an ability to catalyze both ammonia and nitrite oxidation (complete ammonia oxidizers-Conammox). Denitrification consists of a series of $\mathrm{N}-\mathrm{NO}_{3}$ reductions with gaseous $\mathrm{N}_{2}$ with nitrite, nitric and nitrous oxide as intermediates, and is carried out by a number of heterotrophic denitrifiers represented in all the main phylogenetic groups.

In recent years, the autotrophic nitrogen removal process has also been discovered, containing partial nitrification to $\mathrm{N}-\mathrm{NO}_{2}$, which is then an electron acceptor for anaerobic ammonium oxidizers (AnAOB) [16].

However, the presence of N-FAN causes a strong toxic impact on a variety of key organisms related to all the abovementioned nitrogen degradation processes. Possible mechanisms of ammonia toxicity have been postulated by Kadam and Boone [17] based on methanogenic bacteria investigations: first by 
inhibition of the cytosolic enzymes activity by $\mathrm{NH}_{3}$ and the second as an effect of $\mathrm{N}-\mathrm{NH}_{4}$ accumulation on intracellular $\mathrm{pH}$ or the concentration of other cations, mainly $\mathrm{K}^{+}$. The protons absorbed by $\mathrm{NH}_{3}$ molecules can also lead to alkalization of the cytosol. The inhibitory effect of N-FAN on the wastewater treatment process has been extensively described by Liu et al. [18] In turn, these authors quotes two main mechanisms of N-FAN toxicity on bacteria: inhibitory and biocidal. In the first mechanism, $\mathrm{N}-\mathrm{FAN}$ at the inhibitory level passively diffuses through the cell membrane causing $\mathrm{H}^{+}$imbalance and/or $\mathrm{K}^{+}$deficiency leading to cell activity inhibition. N-FAN could also directly inhibit some key enzymes involved in hydrolysis, acetogenesis, methane production or sulfate reduction, but inhibition on the different enzymes could differ substantially. The biocidal mechanism is based on fact that some bacteria have cell membrane-bound enzymes protected by an extracellular polymeric substance. These substance can be disintegrated in the presence of N-FAN, and consequently the enzymes can be disrupted, causing inactivation or even lysis of the cell.

The ammonia stripping process is based on the principle of mass transfer, and when ammonia solution is contacted with air, a gaseous form can be transferred into the atmosphere. The relative concentrations of both forms are influenced by $\mathrm{pH}$ and temperature, which increases shifts in the chemical equilibrium and induces N-FAN formation [19].

Theoretically, at a temperature of $20^{\circ} \mathrm{C}$ and a $\mathrm{pH}$ of 9 , the N-FAN can reach over $40 \%$ of N-TAN. However, to ensure effective stripping in practice, the LFL must be brought to $\mathrm{pH}>11$ and then blown counter-currently with a stream of hot air, which implies a high energy consumption, and moreover demands further $\mathrm{pH}$ re-adjustment for the next stage of treatment or discharge [20]. For example, the $\mathrm{pH}$ preferred for the biological nitrification varies between 8 and 9, with less than $50 \%$ of the optimum rate occurring outside the range of 7.0 to 9.8 [21].

An alternative approach would be a combination of those two processes in one reactor for the treatment of LFL characterized by a relatively high $\mathrm{pH}$, without the addition of extra alkalis, such as lime, for example. In such a reactor, the method of aeration would be of key importance; it should ensure a sufficient mass of air to sustain the nitrification and effective stripping, but at the same time the anoxic zones are preferred by heterotrophs. The implementation of sequential hybrid bioreactors (HSBR) seems to be promising because of the potential to maintain the biomass and air/oxygen gradation.

Therefore, the aim of the study was to determine whether the simultaneous biological and physical removal of ammonia can be achieved in a single HSBR reactor. Over the course of this study, alternative variants of aeration were investigated in terms of biological nitrogen and organic compound removal efficiency. Obtained data were supported by quantitative analysis of chosen bacteria groups.

\section{Materials and Methods}

\subsection{Leachate Sampling}

The LFL was gathered from landfill being a part of regional installation for municipal waste treatment (Kozodrza, Subcarpathian Province, Poland). The installation has been operated continuously since 1990 and has the ability to receive annually over $90 \mathrm{Gg}$ of mixed municipal waste (after process of mechanical segregation). LFL was sampled once from the retention pond $\left(50^{\circ} 07^{\prime} 03.4^{\prime \prime} \mathrm{N} 21^{\circ} 37^{\prime} 04.1^{\prime \prime} \mathrm{E}\right)$ that drains the outflow from currently operated quarters. Samples were transported in $10 \mathrm{~L}$ tanks to the laboratory, where they were immediately analyzed, and used in the experimental procedure. The remaining volume was stored in $4{ }^{\circ} \mathrm{C}$ and in darkness, to prevent microbial activity, and when needed to replenish the supply tank, the temperature was equilibrated to $25^{\circ} \mathrm{C}$ overnight. Raw samples used in the experiment were characterized by a mean concentration of organic compounds expressed as COD of $12258 \mathrm{mg} / \mathrm{L}, \mathrm{BOD}_{5}$ of $494 \mathrm{mg} / \mathrm{L}$, and humic substances of $233 \mathrm{mg} / \mathrm{L}$, therefore $\mathrm{BOD}_{5} / \mathrm{COD}$ had a ratio of 0.04 , which was rather typical for stabilized other than active landfill [2]. However, the organic carbon was twice as high as observed in 2017 on this site [3]. The concentration of nitrogen was also higher; the N-TAN amounted to $1512 \mathrm{mg} / \mathrm{L}$. The salinity of LFL sample, expressed as electric conductivity, was $28.3 \mathrm{mS} / \mathrm{cm}$ and $\mathrm{pH}$ reached a relatively high level of 9.24. 


\subsection{Experimental Set-Up}

In this experiment, LFL was treated in a one-stage biological system composed of two parallel (R1 and R2), independent, glass jar hybrid reactors, $2 \mathrm{~L}$ of working volume each, equipped with submerged fixed biomass carriers (Figure 1). The hydraulic retention time (HRT) was set at 3 days, and a $24 \mathrm{~h}$ cycle consisted of $1.75 \mathrm{~h}$ of sedimentation, $0.15 \mathrm{~h}$ of decantation and subsequent refilling, and $22 \mathrm{~h}$ of mixing and aeration. Both reactors were equipped with a fine bubbles aeration system, but the position of diffusers made the difference between them-R1 was top-aerated, whilst $\mathrm{R} 2$ has a diffuser mounted below the frame clamping to the rim of the biomass carriers (all the features of construction shown on Figure 1). The intensity of the air supply has been valve-regulated to keep a constant value of $\mathrm{DO} \leq 1 \mathrm{mg} / \mathrm{L}$ during the aeration phase, and oxygen distribution was supported by mechanical stirring. The temperature was stabilized at $25^{\circ} \mathrm{C}( \pm 0.1)$ by a control unit composed of a probe, a controller and bottom heaters. The biomass carriers were made of polyurethane-reticulated open-cell foam. To estimate the total area of its complex internal structure, a methodology based on Weaire-Phelan foam-like structure was adopted [22] and the measurements of foam structural elements were taken from fifty randomly selected pores, by optical scanning of foam slices on a calibration grid (ImageJ1 [23]). The results of these calculations are shown in Table 1.

A

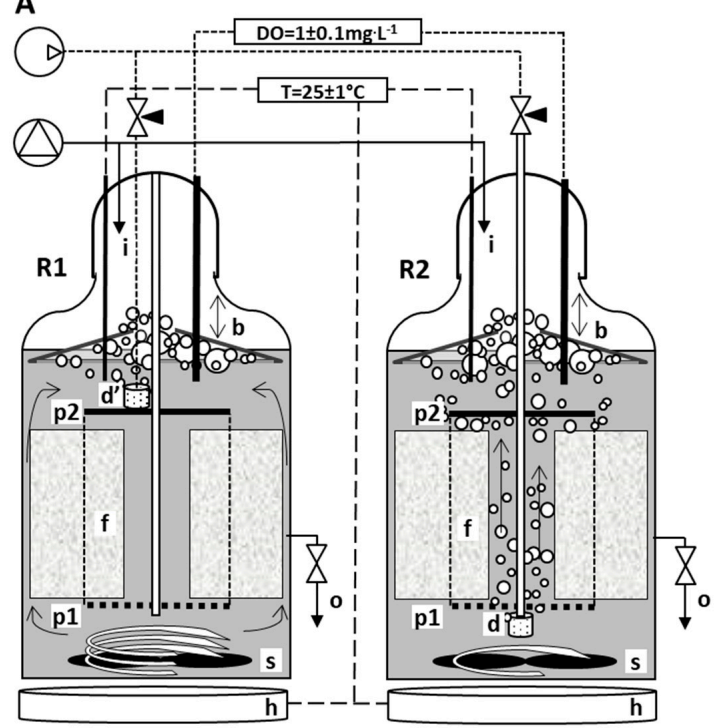

B

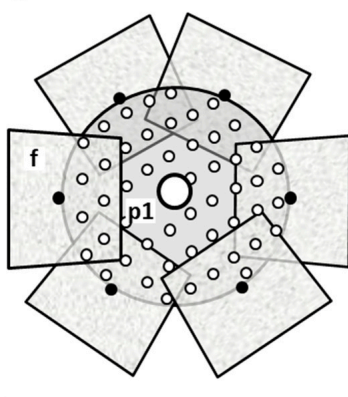

C

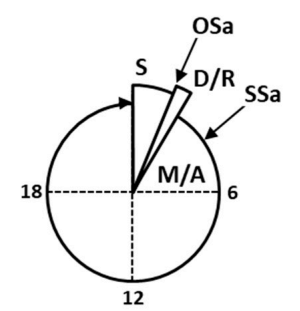

Figure 1. The experimental set-up: lengthwise cross-section through the construction of hybrid sequencing batch reactors; (A) each glass jar with an active volume of $2 \mathrm{~L}$ was equipped with submerged fixed biomass carrier, based on a rigid frame made of straight metal pipe with two plastic plates mounted axially: lower was open-worked (p1), upper was solid (p2). Between plates the rim of cuboids made of reticulated $30 \mathrm{ppi}$ PU foam (f) was attached, then plates were rotated by about $30^{\circ}$ to slightly contort cuboids spirally according to the stirring direction, to create outer canals (B) — top view on the bed construction). Two aeration variants were tested: in R1 the fine bubble diffuser was mounted on the surface of the upper plate $\left(\mathrm{d}^{\prime}\right)$, in R2 the air was delivered through the central pipe to the diffuser (d) mounted below the carriers. Mass and temperature transport in R1 was supported by stirrer $(\approx 300 \mathrm{rpm}$ ), while in R2 speed of rotation was set only to avoid building up the residue on the bottom of the reactor. Both reactors were equipped with temperature probes coupled with heaters (h), as well as DO probes, allowing the regulation of air valves to maintain constant oxygen concentration. Cone-shaped plastic collars (b), with limited vertical movement, acted as mechanical froth breakers to avoid flotation of biomass by strongly foaming leachate. SBRs were fed from the top (i) and the operational sequence lasting $24 \mathrm{~h}$ (C) consisted of $1.75 \mathrm{~h}$ of sedimentation (S), $0.15 \mathrm{~h}$ of decantation and refilling (D/R, HRT $=3$ days) and $22 \mathrm{~h}$ of mixing and aerating $(\mathrm{M} / \mathrm{A})$. The outflow (o) was sampled (OSa) during the decantation phase, whilst sludge samples (Ssa) were collected every five days, about one hour after M/A was started. 
Table 1. Characteristics of the material used as biomass carrier.

\begin{tabular}{ccc}
\hline Parameters & Units & \\
\hline Material & Reticulated (Open Cell) & Polyurethane (Polyether) \\
\hline Porosity (linear) declared by manufacturer & $\mathrm{ppi}$ & 30 \\
Size of one component (cuboid) & $\mathrm{cm}$ & $3 \times 3 \times 10$ \\
Number of cuboids in bed & - & 6 \\
Cuboids geometrical area and volume & $\mathrm{cm}^{2} / \mathrm{cm}^{3}$ & $828 / 540$ \\
Measured mean strut length & $\mathrm{Mm}$ & $1.278(0.366)$ \\
$\mathrm{k}_{\text {A }}$ (pore opening coefficient) & - & 0.272 \\
Estimated single cell volume & $\mathrm{cm}^{3}$ & 0.015 \\
Estimated single cell surface area & $\mathrm{cm}^{2}$ & 0.088 \\
Est. total inner surface area & $\mathrm{cm}^{2}$ & 3168 \\
Est. specific surface area & $\mathrm{cm}^{2} / \mathrm{cm}^{3}$ & 5.867 \\
Est. total outer surface area & $\mathrm{cm}^{2}$ & 400.575 \\
Est. total area of biomass carriers & $\mathrm{cm}^{2}$ & 3568.575 \\
\hline
\end{tabular}

Reactors were inoculated once, at the start of the experiment, by an addition of $0.8 \mathrm{~L}$ (MLSS $=4.0 \mathrm{~g} / \mathrm{L}$ ) of suspended activated sludge taken from nitrification tank of local municipal wastewater treatment plant (PE $\approx 200,000$ ). Before the introduction to the HSBRs, sludge was washed three times in tap water. Before the inoculation, both reactors were filled up with LFL and the whole operational cycle was executed to assess the potential of physical stripping of ammonia; in both reactors, only trace amounts of nitrogen (up to $5 \%$ ) were removed without the involvement of microbial activity.

\subsection{Physio-Chemical Analyzes}

Analyses of physio-chemical parameters were performed using methods which complied with the Polish Standards (Table 2). In the absence of other forms of mineral nitrogen in raw LFL ( $\mathrm{N}-\mathrm{NO}_{2}$ and $\mathrm{N}-\mathrm{NO}_{3}$, data not included in tables), except ammonium, the value of $\mathrm{N}-\mathrm{N}_{\mathrm{K}}$ reduced by $\mathrm{N}-\mathrm{N}_{\text {org }}$ was practically equivalent to N-TAN. The concentration of N-FAN $(\mathrm{mg} / \mathrm{L})$ in LFL was estimated using the following formula [24]:

$$
\mathrm{N}-\mathrm{FAN}=\frac{\mathrm{N}-\mathrm{TAN}}{1+10^{(\mathrm{pKa}-\mathrm{pH})}}
$$

where the dissociation constant $(\mathrm{pKa})$ is calculated from the formula below.

$$
\mathrm{pKa}=0.09108+\frac{2729.92}{\mathrm{~T}}
$$

where $\mathrm{T}$ is the temperature in Kelvin. The ammonium nitrogen was removed from LFL in accordance with the first-order reaction [25]:

$$
\mathrm{r}=\frac{\mathrm{dC}_{\mathrm{N}}}{\mathrm{dt}}=-\mathrm{k} \times \mathrm{C}_{\mathrm{N}}
$$

where the relation between the concentration and time is expressed as:

$$
\mathrm{C}_{\mathrm{N}}=\mathrm{C}_{0} \cdot \exp (-\mathrm{k} \times \mathrm{t})+\mathrm{C}_{\mathrm{e}}
$$

where $\mathrm{C}_{\mathrm{N}}$ is nitrogen concentration $(\mathrm{mg} / \mathrm{L}), \mathrm{C}_{0}$ is ammonium concentration at the beginning of the HSBR cycle (mg/L), $C_{e}$ is ammonium concentration at the end of the HSBR cycle $(\mathrm{mg} / \mathrm{L}), \mathrm{k}$ is constant of the nitrogen removal rate $\left(\mathrm{h}^{-1}\right), \mathrm{r}$ is nitrogen removal rate $(\mathrm{mg} / \mathrm{L} \cdot \mathrm{h})$ and $\mathrm{t}$ is time $(\mathrm{h})$. 
Table 2. Physio-chemical analyses and methods of the measurement.

\begin{tabular}{|c|c|c|}
\hline Parameter & Method & Description, Device and Reference to Analytical Standard \\
\hline $\mathrm{pH}$ & Potentiometric & Elmetron CPC-401, [26] \\
\hline k & Conductometric & Elmetron CPC-401, [27] \\
\hline DO & Membrane electrode & Elmetron CX 105 \\
\hline COD & Colourimetric. & $\begin{array}{l}\text { Oxidation of organic substances with } \mathrm{K}_{2} \mathrm{Cr}_{2} \mathrm{O}_{7} \text { and } \mathrm{H}_{2} \mathrm{SO}_{4} \text { in the presence } \\
\text { of } \mathrm{Ag}_{2} \mathrm{SO}_{4} \text { as a catalyst, at } 172{ }^{\circ} \mathrm{C} \text {, [28] }\end{array}$ \\
\hline $\mathrm{BOD}_{5}$ & Respirometric & $\begin{array}{l}\text { Measurement of negative pressure at constant temperature of } 20^{\circ} \mathrm{C} \text { and } \\
\text { dark in presence of N-allythiourea as nitrification inhibitor, OxiTop }{ }^{\circledR},[29]\end{array}$ \\
\hline $\mathrm{N}-\mathrm{N}_{\mathrm{K}}$ & Colourimetric. & $\begin{array}{l}\text { Oxidation of nitrogen containing compounds in concentrated } \mathrm{H}_{2} \mathrm{SO}_{4} \text { in } \\
\text { presence of } \mathrm{K}_{2} \mathrm{SO}_{4} / \mathrm{HgO} \text { catalyst, [30] }\end{array}$ \\
\hline $\mathrm{N}-\mathrm{NH}_{4}$ & Colourimetric. & $\begin{array}{l}\text { Distillation of sample in weakly alkaline conditions and titration with } \\
\text { Tashiro's indicator, VELP, [31] }\end{array}$ \\
\hline $\mathrm{N}-\mathrm{NO}_{2}$ & Spectrophotometric & $\begin{array}{l}\text { Absorbance for } \lambda=520 \mathrm{~nm} \text { with sulfanilic acid and } \\
\mathrm{N}-(1-N a p h t h y l) e t h y l e n e d i a m i n e \\
\text { dihydrochloride, Shimadzu, [32] }\end{array}$ \\
\hline $\mathrm{N}-\mathrm{NO}_{3}$ & Spectrophotometric & Absorbance for $\lambda=410 \mathrm{~nm}$ with phenol disulfonic acid, Shimadzu, [33] \\
\hline TSS & Weighing & Residuals after $2 \mathrm{~h}$ at $105^{\circ} \mathrm{C}$, Radwag \\
\hline VSS & Weighing & Residuals after incineration for $2 \mathrm{~h}$, at $550{ }^{\circ} \mathrm{C}$, Radwag \\
\hline
\end{tabular}

\subsection{DNA Sampling and Analyses}

Every five days, over one hour after starting the mixing/aerating phase, the reactors were gently shaken to release the sludge from the biomass carriers, then up to $20 \mathrm{~mL}$ of mixed liquor was sampled from each. Samples were immediately centrifuged for $10 \mathrm{~min}$ (3000 rcf), decanted supernatant was poured back to the SBRs and the remaining residue transferred to $1.5 \mathrm{~mL}$ Eppendorf tubes, centrifuged again for $10 \mathrm{~min}(6000 \mathrm{rcf})$ and re-suspended in sodium-phosphate buffer $(0.0125 \mathrm{M}$, $5 \%$ SDS), then stored at $-20{ }^{\circ} \mathrm{C}$ for further analysis. Immediately after the thawing, $0.5 \mathrm{~mL}$ of each sample was centrifuged for $10 \mathrm{~min}(6000 \mathrm{rcf})$, and the resulting pellet was used for DNA extraction according to the protocol of the manufacturer (Genomic Mini AX Bacteria + Spin, A\&A Biotechnology, Gdynia Poland). The lysis step was based on the activity of mutanolysin, lysozyme and proteinase K, which was followed by purification on ion-exchange microcolumns, and DNA was eluted into $150 \mu \mathrm{L}$ of a provided buffer.

Based on data regarding the relative abundance of taxons commonly identified in LFL treatment systems [34-37], a set of PCR primers was adopted to amplify fragments of the bacterial $16 \mathrm{~S}$ rRNA gene (926F/1062R), Bacteroidetes (Cfb798F/967R), Firmicutes (Firm928F/1040R), Actinobacteria (Act920F3/1200R, [38]), Betaproteobacteria (Beta979F/1130R, [39]) and Gammaproteobacteria (Gamma1080F/1202R, [38]). This set was completed with primers universal for most of AnAOB $16 S$ rRNA (Amx694F/960R of [40]).

Quantitative PCRs were performed in LightCycler ${ }^{\circledR} 96$ (Roche, Rotkreuz, Switzerland) and thermal profiles were defined as follows: $300 \mathrm{~s}$ of predenaturation in $95^{\circ} \mathrm{C}$, then up to 45 cycles containing: $15 \mathrm{~s}$ in $95^{\circ} \mathrm{C}, 15 \mathrm{~s}$ in $61^{\circ} \mathrm{C}$ or $60^{\circ} \mathrm{C}$ (Betaproteobacteria) or $55^{\circ} \mathrm{C}$ (AnAOB), and $20 \mathrm{~s}$ in $72{ }^{\circ} \mathrm{C}$. Reaction mix consisted of $10 \mu \mathrm{L}$ of RealTime 2xPCR Master Mix SYBR A (A\&A Biotechnology, Gdynia, Poland), $1 \mu \mathrm{L}$ of each primer (10 mM, Genomed), $2 \mu \mathrm{L}$ of DNA template and nuclease-free water added to a total volume of $20 \mu \mathrm{L}$. Amplifications were validated by melting curves inspection and randomly chosen samples were electrophoresed in $\mathrm{EtBr}$ stained $2 \%$ agarose gel, for up to two hours (3 V/cm, 1xTBE). All reactions were triplicated and included negative reagent controls.

To determine the reaction yield, quantitative standards were prepared; tDNA sample was isolated from activated sludge freshly collected from a wastewater treatment plant, each gene fragment has been amplified (WALK DNA Pwo Polymerase, A\&A Biotechnology, Gdynia, Poland; Mastercycler, Eppendorf, Hamburg, Germany) and electrophoresed, then the amplicon bands were extracted from gel and purified on a silica column (Gel-out, A\&A Biotechnology, Gdynia, Poland), resuspended in TE buffer, and reamplified. The obtained products were purified once again on silica columns (Clean-Up, A\&A Biotechnology, Gdynia, Poland). Molecular weight (bp) and quantity of DNA (ng) in each band was determined [41] by quantitative electrophoresis in EtBr-stained 1.8\% agarose gel, 
in the presence of an equimolar $100 \mathrm{bp}$ ladder (Carl Roth, Germany). To calibrate molecular weight the electrophoresis, curves were fitted to log-linear function, whilst quantities were estimated on the quadratic model. Based on this data, the approximate number of DNA molecules in stock concentration was calculated, then standards were diluted in 10-fold series and added to the PCR reaction in equal volumes. The results of qPCR measurements were re-calculated per one $\mathrm{mL}$ of the reactor active volume, considering all changes of sample concentrations during subsequent laboratory procedures.

\subsection{Statistical Analysis}

Differences in physio-chemical parameters, as well as the number of DNA copies between the outflows from reactors (R1 and R2), were tested by nonparametric Mann-Whitney-Wilcoxon (M-W) test. Moment of stabilization was arbitrarily determined from the course of ammonia concentration curve. Besides the distribution of the obtained data, the test was chosen because of its resistance to extreme outliers, and its small sample size. Moreover, nonparametric Spearman's rank correlation coefficients were determined to describe the relations between concentration of nitrogen forms and bacterial 16S rRNA gene abundance. All statistical analyses were performed by analytics software package Statistica (Version 13.3, TIBCO Software Inc., Palo Alto, CA, USA).

\section{Results and Discussion}

\subsection{Removal of Organic and Nitrogen Compounds}

LFL inflowing to the reactors had an initial concentration of organic compounds expressed by chemical oxygen demand exceeding $12 \mathrm{~g} / \mathrm{L}$, of which $\mathrm{BOD}_{5}$ accounted only for $4 \%$, and humic substances even less than $2 \%$. Thus, a load of organic compounds in the inflow was $8090.3 \mathrm{mg} / \mathrm{day}$, whilst a load of humic substances was $153.83 \mathrm{mg}$ /day. The volumetric organic loading rate (OLR) was $4.04 \mathrm{~kg} / \mathrm{m}^{3}$.day, and the nitrogen loading rate (NLR) $0.498 \mathrm{~kg} / \mathrm{m}^{3} \cdot$ day. Since N-TAN was the only form of mineral nitrogen detected in LFL, at the level of $1.5 \mathrm{~g} / \mathrm{L}$, organics were anticipated to be effectively removed neither during the start-up of both reactors nor in their further continuous operation. In fact, as it clearly arises from the data presented in Figure 2, there were no significant differences in COD values between outflows from $R 1$ and $R 2\left(M_{R 1}=11,183.3, \sigma=1020 ; M_{R 2}=10,466.7\right.$, $\sigma=1743$ ). This resulted in the average efficiency of organic compound removal at the levels of $9.09 \%$ and $14.90 \%$, and $17.22 \%$ and $12.29 \%$ for HS, respectively for R1 and R2 (Figure 2). The literature review shows that absorption may be one of the means of HS removal [42].

Interestingly, in the course of the experiment, there are no observed changes or significant differences between the reactors in VSS value, which can be seen in Figure $2\left(\mathrm{M}_{\mathrm{R} 1}=4381.7 \mathrm{mg} / \mathrm{L}\right.$; $\sigma=429.6, \mathrm{M}_{\mathrm{R} 2}=4150.83 \mathrm{mg} / \mathrm{L} ; \sigma=386.0, \mathrm{p}_{\mathrm{M}-\mathrm{W}}=0.326$ ).

However, there was an increase in observed TSS concentrations in outflows, but not in the absence of statistical differences between the reactors. In this case, the TSS could be considered as an indicator of the outflows of stabilization; its concentration had increased linearly in both reactors, at a similar pace until the 18th day of the experiment (according to the Equation $y=456.8 x+2893.6$ for $\mathrm{R} 1$, and $\mathrm{y}=451 \mathrm{x}+2462$ for $\mathrm{R} 2$, with $\mathrm{R}^{2}=0.99$ in both), then it remained at a similar level $\left(\mathrm{M}_{\mathrm{R} 1}=10,866.7 \mathrm{mg} / \mathrm{L}, \sigma=362.8 ; \mathrm{M}_{\mathrm{R} 2}=10,706.7 \mathrm{mg} / \mathrm{L}, \sigma=134.4\right)$. Thus, VSS content in total solids outflowing from the reactors at the start amounted to $54.81 \%$ in SBR1 and $54.96 \%$ in SBR2, then dropped to the mean value of $28.13 \%(\sigma=1.6)$ and $27.34 \%(\sigma=1.7)$ respectively, which can be explained by effective biomass attaching to the surface of the carrier structure. The weight of TSS accumulated inside the foam structure at the end of the experiment was $19.87 \mathrm{~g}$ in R1 and $17.62 \mathrm{~g}$ in R2, which, after conversion, gives 5.57 and $4.94 \mathrm{mg}$ per square centimeter of an estimated total surface of biomass carrier. A simple observation made after the experiment showed that short, manual shaking of the whole reactor caused visible precipitation of a few centimeters' layer of activated sludge released from the carriers, but after just a few hours of mixing/aerating, the entire sludge had been built back into the biomass carrier. Thereby, there is a certain difficulty in quantifying such biological parameters as 
bacterial abundance in systems equipped with porous biomass carriers when each measurement could be only a derivative of the actual number of organisms inhabiting internal structure of the fills.

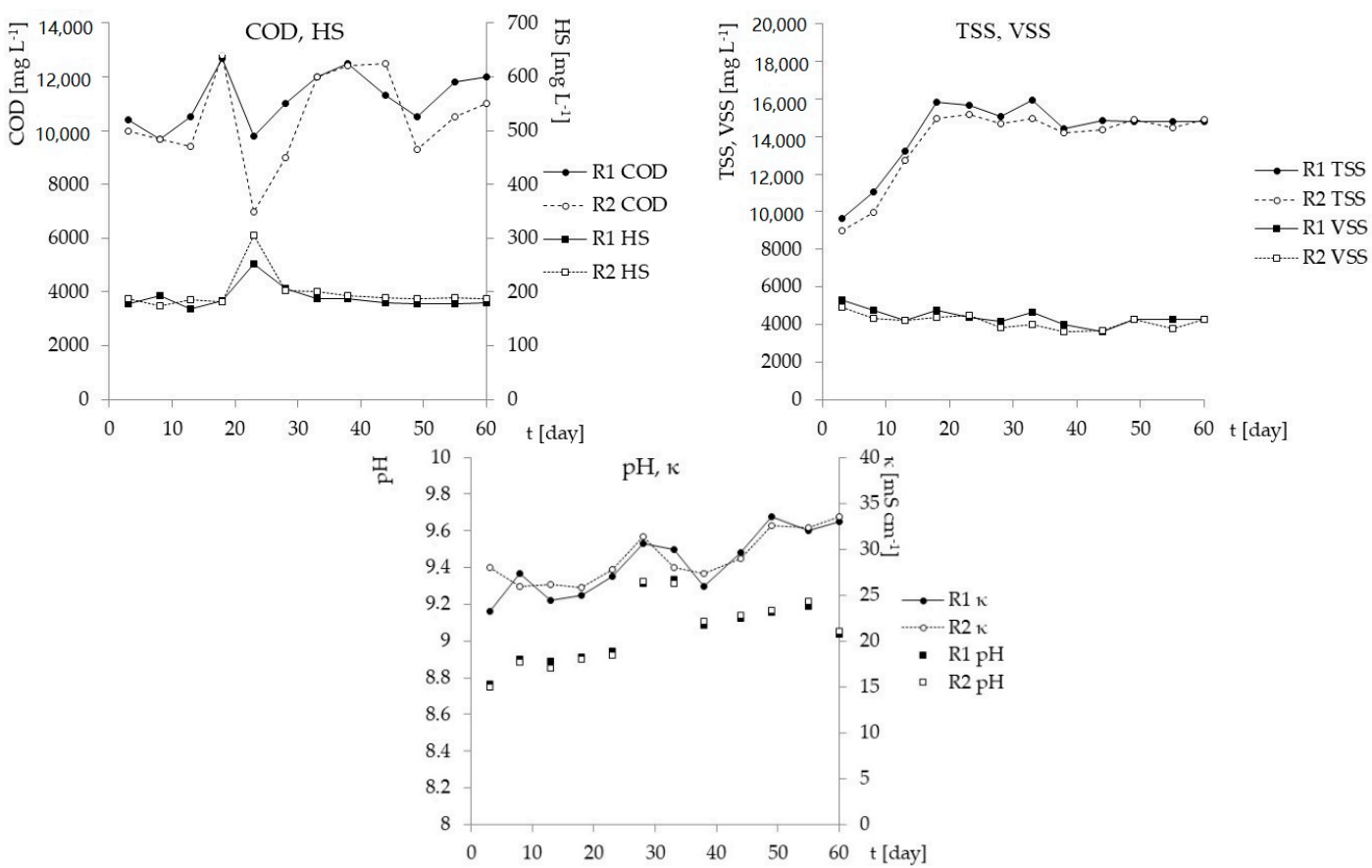

Figure 2. Physio-chemical characterization (COD, HS, TSS, VSS, $\mathrm{pH}$ and $\mathrm{k}$ ) of the outflows from R1 (black points, solid lines) and R2 (white points, dotted lines) in subsequent days of the experiment. Box-plot graphs show quartiles (box) and range (whiskers). No significant differences were observed between the reactors.

The raw LFL was characterized by a mean concentration of $\mathrm{N}-\mathrm{N}_{\mathrm{K}}$ at the level of $1600 \mathrm{mg} / \mathrm{L}$, including $94.5 \%$ of N-TAN. Thus, a load of nitrogen in the inflow was $997.92 \mathrm{mg} / \mathrm{day}$. Neither nitrites nor nitrates were detected in the LFL sampled from landfill retention tank, as well as in the outflows from HSBRs after the treatment.

The temperature and $\mathrm{pH}$ in the biological systems treating wastewater highly loaded with ammonium nitrogen have a crucial impact on N-FAN concentration. As the scientific data confirms, a high concentration of N-FAN can promote nitrite accumulation by selective inhibition of nitrite-oxidizing bacteria (NOB), over the ammonia oxidizers (AOB) [43]. Akgul et al. [44] report that at a $\mathrm{pH}$ above 8.7, the concentration of N-FAN was about $550 \mathrm{mg} / \mathrm{L}$ and $\mathrm{N}-\mathrm{NH}_{4}-2281 \mathrm{mg} / \mathrm{L}$,

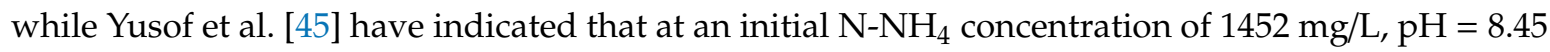
and a temperature of $25{ }^{\circ} \mathrm{C}$, the concentration of N-FAN amounted to $243 \mathrm{mg} / \mathrm{L}$. In this study, the temperature of the process was constantly maintained at $25 \pm 1{ }^{\circ} \mathrm{C}$, so the $\mathrm{pH}$ that was slightly increasing till the end in both HSBRs, from 9.2 to $>9.6$ (Figure 2), was the main parameter influencing N-FAN concentration. N-FAN concentration in outflows has been stabilized after three weeks of running the process, and amounted on average to $251.2 \mathrm{mg} / \mathrm{L}$ in $\mathrm{R} 1$ and even to $739.7 \mathrm{mg} / \mathrm{L}$ in R2 (Figure 3). The literature data suggest that N-FAN inhibits the ammonia oxidizing bacteria (AOB) in a concentration which ranged from 10 to $150 \mathrm{mg} / \mathrm{L}$, and nitrite oxidizing bacteria (NOB) even at $0.1 \mathrm{mg} / \mathrm{L}$ [24]. Equation (1) underlines the role of $\mathrm{pH}$ and temperature rather than the concentration of ammonia, in the estimation of free ammonia concentration [46], therefore some authors recommend supplementation of buffering agents, but in proportion to $\mathrm{N}-\mathrm{NH}_{4}$, to enhance the biological process. 

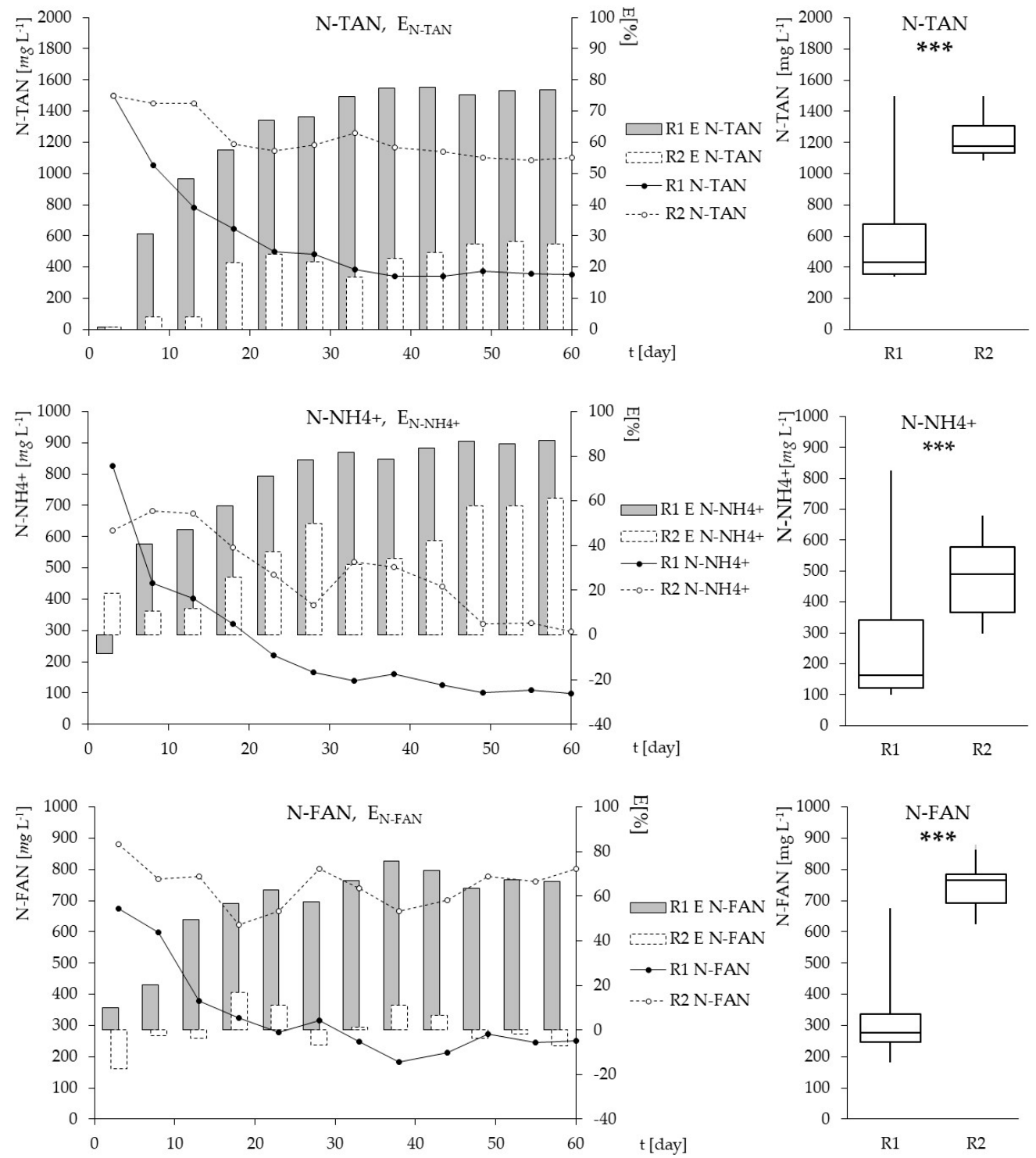

Figure 3. The dynamics of nitrogen forms concentration in the outflows from R1 (black points, solid lines) and R2 (white points, dotted lines), in subsequent days (d) of the experiment, and their removal efficiency (grey bars-R1, white bars-R2). Box-plot graphs show quartiles (box) and range (whiskers). The probability values of M-W test were smaller than 0.001 in all cases $\left.{ }^{* * *}\right)$.

Akgul et al. [44] noticed, that when NLR in the influent amounts to $0.47 \mathrm{~kg} / \mathrm{m}^{3} \cdot$ day, the ammonium nitrogen removal efficiency can reach $74 \%$, and $65 \%$ of the removed ammonia is converted to nitrite. In this work, with an inflowing NLR of $0.498 \mathrm{~kg} / \mathrm{m}^{3}$.day, neither nitrite nor nitrate were found in the outflow. Although the efficiency of N-TAN in the top-aerated reactor (R1) reached 76.8\%, whilst in the reactor with bottom-aeration system (R2) it only reached 27.2\% (Figure 3). In turn, van Dongen et al. [47] report that with NLR of $1.2 \mathrm{~kg} / \mathrm{m}^{3}$. day, even over $80 \%$ of ammonium nitrogen has been converted to molecular nitrogen. In previous studies, Koc-Jurczyk and Jurczyk [22] have obtained that the efficiency of ammonium nitrogen removal ranged from $46.3 \%$ to $77.6 \%$, depending on the porosity of the PU foam utilized as a biomass carrier. Wherein, the test was run in reactors intense aerated from the bottom $(\mathrm{DO}=2 \mathrm{mg} / \mathrm{L})$, and the carriers had the form of a submerged, loosely attached bunch of polymeric foam, without internal straight-run channels, that supports mass and temperature exchange. The best results were obtained with the linear porosity of $30 \mathrm{ppi}$, such as in the foam used in the current experiment. 
Analyzing the nitrogen removal efficiency at such high $\mathrm{pH}$ values, all of its forms should be considered to emphasize the differences between differently aerated reactors (Figure 3). The low removal efficiency of N-TAN in 2 consisted of the biological removal of $\mathrm{N}^{-\mathrm{NH}_{4}}$ with a mean efficiency of $44.2 \%$, and marginal, only a few-percent, removal of N-FAN. This results in nitrogen accumulation. In turn, in the $\mathrm{R} 1$, over three-times higher $\mathrm{N}-\mathrm{TAN}$ removal resulted from $\mathrm{N}-\mathrm{NH}_{4}$ removal reaching $87 \%$, and a quite high removal of over $66 \%$ N-FAN.

More information is provided by kinetic analysis of diurnal operational cycle (Figure 4). The kinetics of nitrogen removal was tested after stabilization of concentrations in the outflows. The reaction rate constant $k$ was higher for $\mathrm{R} 2$ than for $\mathrm{R} 1$. Moreover, the reaction rate $r$, calculated in accordance with Equation (4), was straightly higher in R2 (Table 3). However, in R2 ammonia removal occurred most intensively during the first $3 \mathrm{~h}$ and was stopped later. In the case of the top-aerated reactor, the intense removal took place over the first $8 \mathrm{~h}$ and still occurred until the end of cycle, thus correlation coefficients for first order reaction were higher for $\mathrm{R} 1$ and $\mathrm{N}-\mathrm{NH}_{4}$.

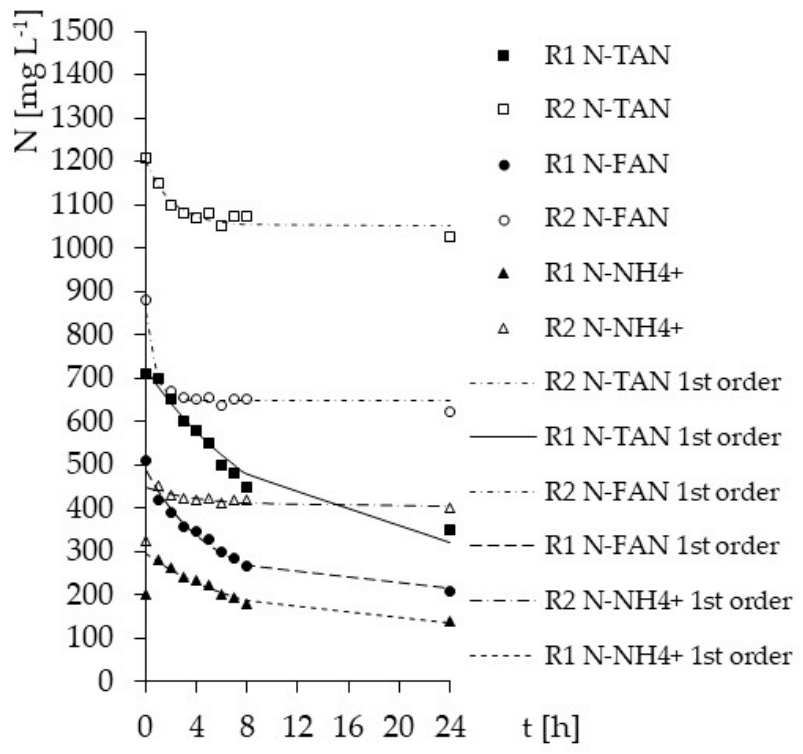

Figure 4. The kinetics of ammonia forms removal during the operational cycle.

Table 3. Parameters describing ammonia/ammonium removal kinetics.

\begin{tabular}{|c|c|c|c|c|c|c|}
\hline & \multicolumn{3}{|c|}{ SBR 1} & \multicolumn{3}{|c|}{ SBR 2} \\
\hline & N-TAN & N-FAN & $\mathrm{N}-\mathrm{NH}_{4}$ & N-TAN & N-FAN & $\mathrm{N}-\mathrm{NH}_{4}$ \\
\hline $\mathrm{C}_{0}\left[\mathrm{mg} \mathrm{L}^{-1}\right]$ & 440 & 275 & 160 & 150 & 205 & 45 \\
\hline $\mathrm{k}\left[\mathrm{h}^{-1}\right]$ & 0.1 & 0.2 & 0.13 & 0.48 & 1.4 & 0.22 \\
\hline $\mathrm{r}\left[\mathrm{mg} \mathrm{L}^{-1} \mathrm{~h}^{-1}\right]$ & 44 & 55 & 20.8 & 72 & 287 & 9.9 \\
\hline conformity factor & 0.0286 & 0.0446 & 0.022 & 0.077 & 0.0446 & 0.0138 \\
\hline correlation coefficient & 0.876 & 0.872 & 0.88 & 0.679 & 0.484 & 0.75 \\
\hline
\end{tabular}

As it was proved by Guo et al. [4], temperature affects not only the efficiency of ammonia removal, but also the reaction rate. Sun et al. [43] achieved rapid growth of nitritation at relatively low temperatures $\left(13.0-17.6^{\circ} \mathrm{C}\right)$ only after 77 days and maintained it by $\mathrm{N}-\mathrm{FAN}$ concentration that inhibits $\mathrm{NOB}$ activity and a reduction of their energy source. In these conditions, AOB became a dominant nitrifying bacteria in the reactor. In turn, Peng et al. [12] inhibited NOB growth by N-FAN concentration, but it almost had no impact on AOB activity. Wang et al. [48], besides the suppression of NOB activity in granular sludge achieved by N-FAN, also used step-feeding to obtain nitritation in only 44 days, while $\mathrm{Gu}$ et al. [49] achieved nitritation even in 40 days by a real-time control strategy including $\mathrm{pH}$ and oxygen supply. This lead to an optimization of the nitrifying bacteria population with AOB as a dominant group. On the other hand, Ramaswami et al. [50] proposed an application of differently 
structured materials as biomass carriers: coke, expanded clay beads and polyethylene molds, to solve the problem of insufficient ammonia retention in membrane treatment systems. The authors stated that such structural parameters of coke as small particle size and rugged surface, supports faster development of biofilm. However, these features also facilitate adsorption of organic compounds, thus promoting the growth of heterotrophic bacteria.

\subsection{Quantitative Dynamics of Bacterial Community}

Quantitative dynamics of selected groups of microorganisms was expressed as a number of group-specific 16S rRNA gene copies, estimated during the course of the experiment (Figure 5). In this work, an approach based on the absolute gene quantification was adopted to the general description of ammonia stripping impact in a single-reactor on key microbial players. The set of primers complementary to ribosomal RNA genes at relatively high taxonomic levels of phylum or class, mostly identified in the LFL treating systems (discussed below), was adopted. The assumption of this generalization was to avoid problems of data interpretation when likely short-term shifts in bacterial communities at the species- or cluster- level occur in reactors inoculated with municipal wastewater sludge but operated by LFL [51].

All of the analyzed groups shown upward trends in abundance over the experiment period. Finally, the total number of bacteria reached $1.09 \times 10^{8} \mathrm{in} \mathrm{mL}$ of top-aerated reactor-active volume (R1) and $7.18 \times 10^{7}$ in $\mathrm{mL}$ of bottom-aerated (R2) (Table 4).

Table 4. Abundance of examined bacteria groups in 3rd, 30th and 60th day of experiment and the results of Spearman's linear correlation between number of DNA copies and the dominant forms of nitrogen in outflows from R1 and R2 (values of $p \leq 0.01$ and $R \geq \pm 0.7$ bolded).

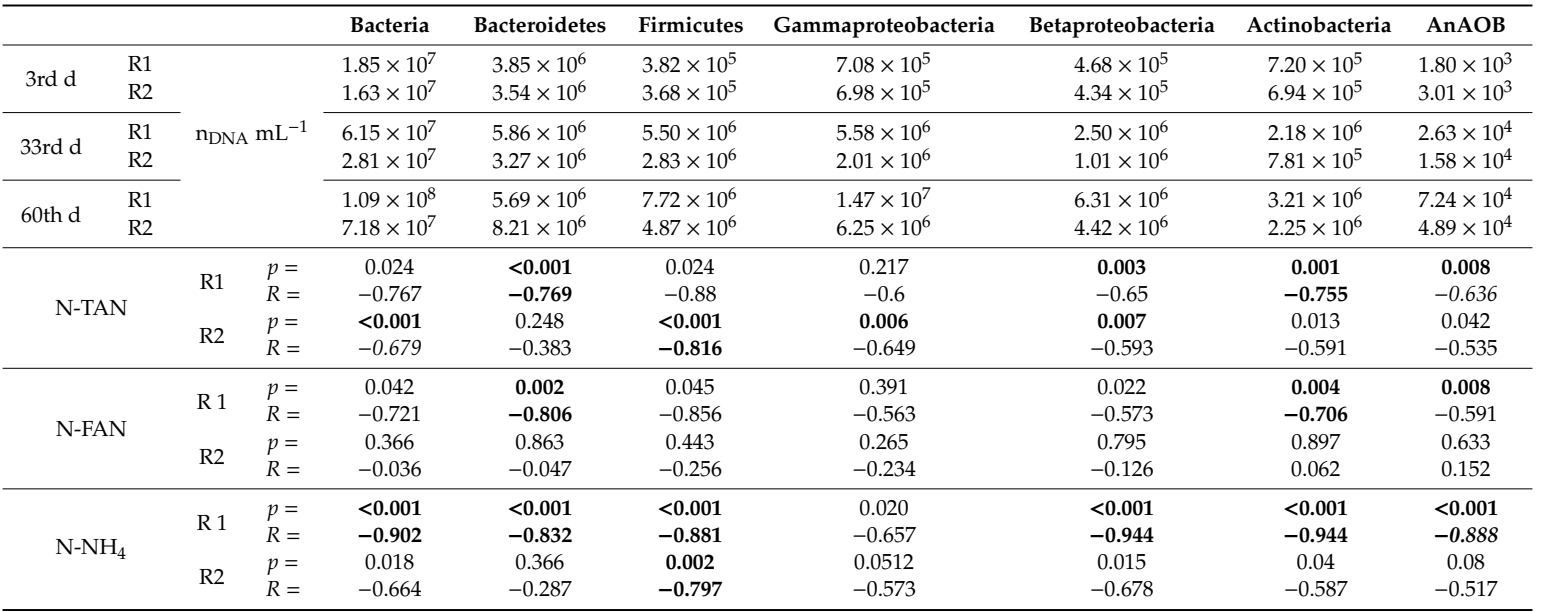

Excluding the first two to four sampling points (before the stabilization of N-TAN in outflows), significant statistical differences were observed in a number of phylum-specific 16S rRNA gene copies at the level of $p<0.05$ between the HSBRs, except Bacteroidetes, Betaproteobacteria and AnAOBs, which could be caused by substantial abundance shifts in these groups. However, in all cases the values of quartiles were higher in R1.

Table 4 displays statistical data concerning the correlation between the number of specific $16 \mathrm{~S}$ rRNA gene copies inside HSBRs and the concentration of mineral nitrogen forms in outflows from HSBRs. Only the cases demonstrating at least statistically significant high correlations $(R>0.69)$, according to Guilford's interpretation, were taken into account. Even on that prudent basis, it is difficult to draw conclusions from the relationship with bacterial abundance, considering only N-TAN concentrations. However, separation of nitrogen forms for the statistical analysis allowed to highlight that no statistically significant correlation was observed in R2 between N-FAN concentration and bacteria quantity, and only Bacteroidetes and Actinobacteria-specific 16S rRNA copies correlated 
negatively with N-FAN (and also N-TAN) in R1. Most of the significant correlations were negative. If the increase of $16 \mathrm{~S}$ rRNA genes copy number corresponds with a decrease of $\mathrm{N}^{-\mathrm{NH}_{4}}$ in the outflow, this simply indicates the biological removal of nitrogen. Following the same reasoning, the increase of N-FAN corresponding with the decrease of bacterial DNA should imply that this form of nitrogen controls the number of bacteria. Therefore, it must be concluded that $\mathrm{N}-\mathrm{NH}_{4}$ removal is a result of biological process as the concentration of this form in R1 is highly negatively correlated with the number of 16S rRNA gene copies for most of the analyzed groups, except Gammaproteobacteria. In R2, only Firmicutes reveals the relationship with N-TAN and $\mathrm{N}-\mathrm{NH}_{4}$ removal.
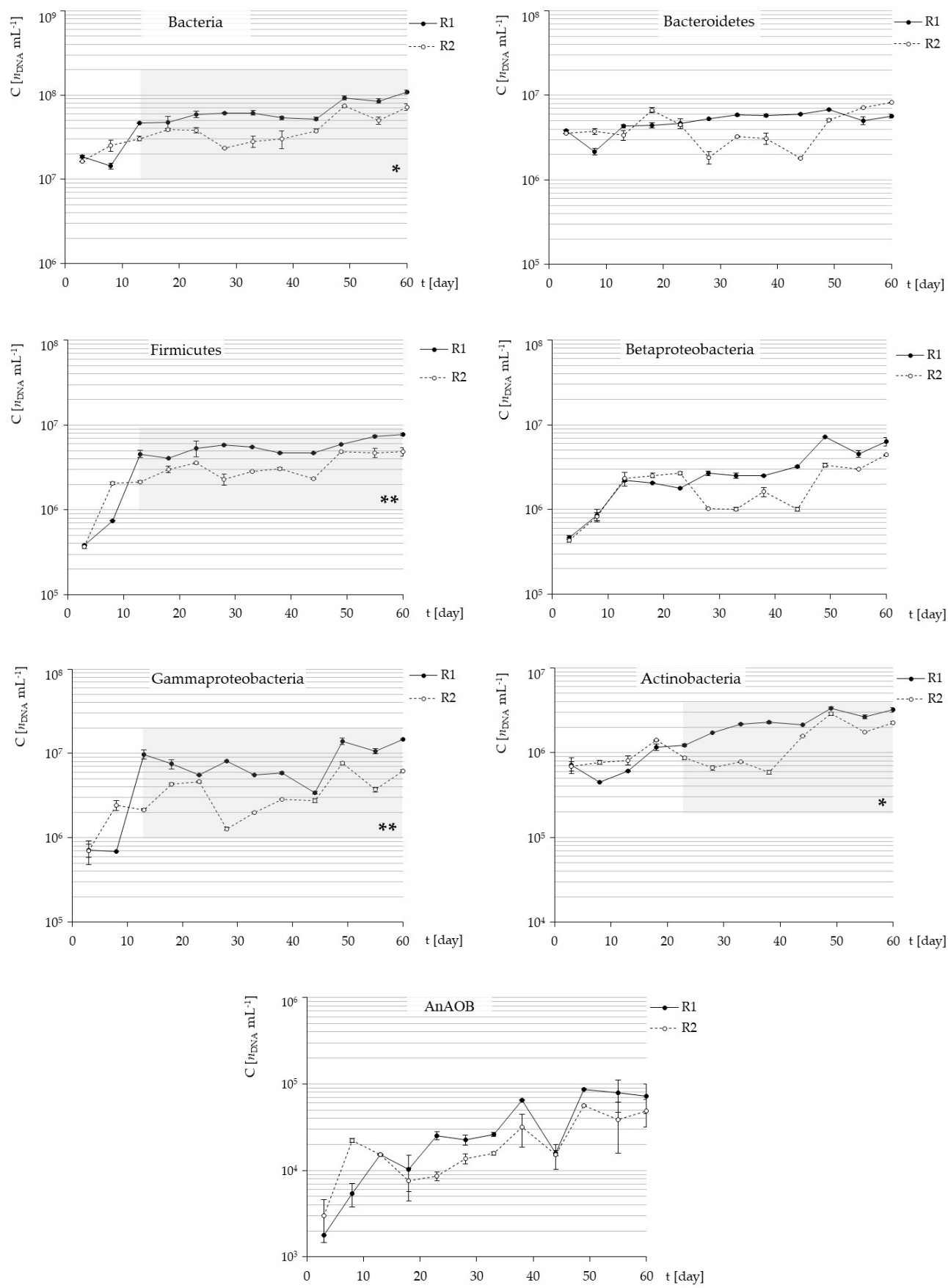

Figure 5. Quantitative dynamics of bacterial 16S rRNA genes during start-up of shallow (R1) and deep aerated (R2) HSBRs treating municipal LFL. Statistically significant $p$-values of M-W statistics calculated from the data collected during the period marked by grey field were shown $\left({ }^{*} p<0.05\right.$, ** $p<0.01)$. 
There is a lack of data combining microbial temporal dynamics with nitrogen removal in systems treating LFL or high-strength $\mathrm{N}_{-} \mathrm{NH}_{4}$ wastewaters. For example, Peng et al. [52] studied the bacterial community in biofilters treating synthetic wastewater with a low carbon/nitrogen ratio. The authors made an attempt to find the relationship between the nitrogen concentrations in effluent and relative abundances of the dominant nitrifying bacteria identified on filter media. Interestingly, between a number of microorganisms, only the Nitrosospira (Betaproteobacteria) played an important indicative role and was significantly negatively correlated with $\mathrm{N}-\mathrm{NH}_{4}$ concentrations in effluent (Pearson $R=-0.807$ ), but not with total nitrogen.

Based on the assumption that the number of bacteria-specific $16 \mathrm{~S}$ rRNA gene copies is a superior set of data that includes most of the lower taxonomic levels, it was used as a reference to estimate the percentage content of the rest of the analyzed groups. Since it was almost an order of magnitude higher than the number of DNA copies specific for the next most abundant groups (Gammaproteobacteria and Bacteroidetes) and was obviously higher than the sum of all the remaining $16 \mathrm{~S}$ rRNA gene copies. Hence, over $66 \%$ of bacteria was not associated with any of the considered groups (Figure 6).

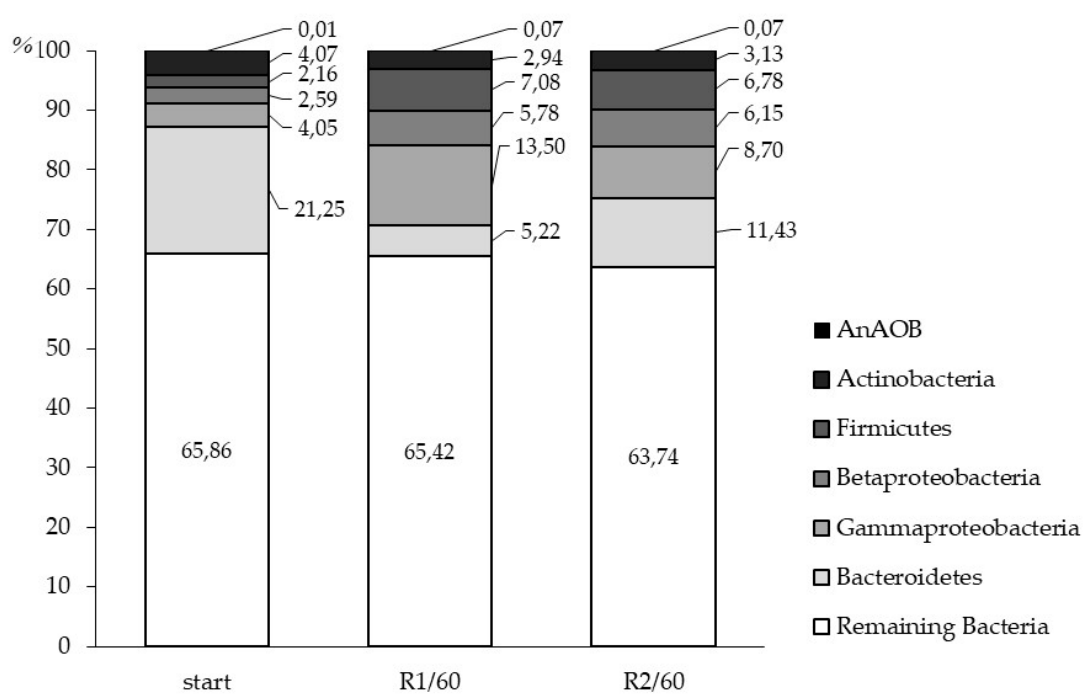

Figure 6. Percentage share of phylum-specific 16S rRNA gene copies after inoculation (mean value) and on 60th day of the experiment in R1 and R2.

Share of unidentified bacteria did not change significantly throughout the experiment, from $65.2 \%$ to $65.3 \%$ in R1, and $63.7 \%$ in R2. After the inoculation and entering of activated sludge into the carriers, the mean percentage share of phylum-specific $16 \mathrm{~S}$ rRNA gene copies was as follows: Bacteroidetes dominates between the analyzed groups, with over $21 \%$, Actinobacteria represents approximately $4.1 \%$, followed by Gamma and Betaproteobacteria with $4 \%$ and $2.6 \%$ respectively, and $2.2 \%$ of Firmicutes. AnAOBs were observed only in trace amounts. Significant changes of the relative abundance structure was observed on 60th day of HSBRs operation; Gammaproteobacteria was the most abundant identified class in R1 with a share of almost $13.5 \%$, followed by Firmicutes raised to $7.1 \%$ and $5.8 \%$ Betaproteobacteria. The most noticeable decrease of $15.6 \%$ was observed in Bacteroidetes, while Actinobacteria abundance did not change significantly. Growth of AnAOBs was noted, despite aerobic conditions, however this group was still in vestigial amounts. In R2, despite Bacteroidetes were twice lowered, phylum remained most numerous with an $11.4 \%$ share, followed by Gammaproteobacteria, which doubled to $8.7 \%$. Firmicutes and Betaproteobacteria percentage share reached similar values like in $\mathrm{R} 1$.

These observations do not coincide, at first glance, with data obtained by the authors cited below. However, in this experiment absolute quantification approach was adopted using standard curves constructed with scalar dilutions of reaction standards when the most of recent data on relative bacteria abundance in bioreactors are based on high throughput sequencing. Besides that this technique allows 
an analysis of previously inaccessible biological resources, it must be taken into consideration that they generally inform about a number of gene variants such as phylotypes that could be assigned to given taxa, but measurements of the actual number of each phylotype copies in volumetric or weight units, is not as precise as in qPCR.

Bacteroidetes and Firmicutes are commonly detected in reactors treating LFL. Representants of this phyla are responsible for hydrolysis of high-molecular compounds and biopolymers. Additionally, Firmicutes are able to survive hyper-salinity conditions, by producing endospores in especially severe periods [2,34,35]. Díaz et al. [53] studied bacterial communities in samples taken from different points of LFL treating Nitrification-Denitrification system. Bacteroidetes and Proteobacteria were dominant in all the samples analyzed. Proteobacteria represented more than $50 \%$ of the total bacteria in both anoxic and oxic reactors, and Betaproteobacteria was the most abundant class. Authors also reported a significant reduction in the relative abundance of Firmicutes phylum after biological treatment compared with raw LFL.

Concentration of DO is a crucial parameter influencing nitrification processes and bacterial abundance. Fudala-Książek et al. [54] in a partial nitrification (PN) reactor, with controlled DO of 0.5-1.5 mg/L, achieved 72 to 99\% ammonia removal, Wei et al. [55] reached $99.1 \%$ at $0.5-1.0 \mathrm{mg} / \mathrm{L}$, whilst Wang et al. [56], treating wastewater highly loaded with ammonia (1.2-1.3 g/L), observed increasing efficiency of ammonia removal with increase concentration of DO from $36 \%$ in $0.5-1.0 \mathrm{mg} \mathrm{O}_{2} / \mathrm{L}$ to $59 \%$ in $2.0-3.0 \mathrm{mg} / \mathrm{L}$, but a further increase to $4.0 \mathrm{mg} / \mathrm{L}$ has an inhibitory effect.

In recent years, numerous molecular data regarding microbial communities in LFL treatment systems have been reported by researchers using various analytic techniques, such as denaturing or temperature gradient electrophoresis (DGGE or TGGE), single-strand conformation polymorphism (SSCP), and lately, new generation sequencing (NGC). However, most of these data concern biodiversity rather than abundance. Therefore, qPCR allows for an interesting comparison of obtained data, and most of all gives the opportunity to correlate biological data with physio-chemical parameters. Zhang et al. [2] have revealed in concentrated LFL: 51.1\% Proteobacteria, 23.4\% of Bacteriodetes and $6.4 \%$ of Firmicutes. Liang et al. [57] analyzed a bacterial community in an Anammox reactor supplied with low COD (0.3-1.0 g/L) and a significant concentration of $\mathrm{N}-\mathrm{NO}_{2}$ ranged from 0.4 to $1.0 \mathrm{~g} / \mathrm{L}$, at a high temperature of $30^{\circ} \mathrm{C}$. They identified DNA sequences mostly classified to Bacteroidetes and Firmicutes phyla, including 45\% of Bacillus sp., 25\% of Paenibacillus sp. and 13\% Staphylococcus sp. Partial nitrification reactors examined by Gabarro et al. [58] based on 16S rRNA gene sequences derived from the DGGE-PCR, was settled mainly by Bacteriodetes (52\%), Alfa and Betaproteobacteria. They also reported that during the experiment the ammonia oxidizer abundance increased from $5 \%$ to $33 \%$, whereas nitrite oxidizers dropped from $2.5 \%$ to only $0.25 \%$.

Xie et al. [34], in a low-temperature reactor, treated LFL characterized by high $\mathrm{N}^{-\mathrm{NH}_{4}}$ concentrations, but also an advantageous BOD/COD ratio of $0.1-1$, identified a rich bacteria community including such phyla as: Gemmatimonadetes, Gammaproteobacteria, Bacteriodetes, Deinococcus-Thermus, Planctomycetes and numerous nitroso- and nitro-bacteria. Xie et al. [36] made an attempt to describe microbial abundance in LFL of a similar composition as described above, but treated in a higher temperature $\left(30^{\circ} \mathrm{C}\right)$ and with a limited oxygen access $(\mathrm{DO}=0.2-0.5 \mathrm{mg} / \mathrm{L})$. In these conditions, Proteobacteria dominated the community with an abundance reaching $46.4 \%$ (including 12.4\% of Gammaproteobacteria and 11.3\% of Betaproteobacteria), followed by Actinobacteria 7.2-16.8\%, Bacteroidetes 3.0-10.3\% and Firmicutes 2.4-7.3\%. AOBs did not exceed 1.78\% and NOBs $0.22 \%$, with Nitrospira at the level of 0.05-0.17\%. Moreover, AnAOB abundance constituted 0.1-0.5\%, while phylum Planctomycetes (3.2-5.4\%) was represented by Candidatus Kuenenia that occurred in less than $0.01 \%$. Xie et al. [35] processed in a high-temperature Anammox membrane reactor the LFL that contained significant amounts of organic carbon, up to $13 \mathrm{~g} / \mathrm{L}$, and also a high load of ammonia, exceeding $3 \mathrm{~g} / \mathrm{L}$. In these experimental conditions authors revealed, by high-throughput 454 pyrosequencing, the structure of a microbial community that contains: $29.7 \%$ of Firmicutes, $27.9 \%$ of Bacteroidetes and only $6.06 \%$ of Proteobacteria. In the same work, an attempt was made to absolute 
quantify the bacterial cells by qPCR. The number of AOB cells was estimated at $1.58 \times 10^{8}$ per gram, and the number of AnAOBs at $1.09 \times 10^{8}$, which gave respectively only $0.41 \%$ and $0.27 \%$ of the total bacteria number.

Silva et al. [37] analyzed the microbial community by pyrosequencing of the hypervariable V3-V4 region in the samples taken from a two-stage system consisting of photo-Fenton followed by activated sludge for treating LFL sampled from a mature landfill. The most abundant phyla in the nitrification reactor were Bacteroidetes with almost $43 \%$, then Proteobacteria with over $32 \%$ (68\% of which was Beta, $21 \%$ Alfa and 9\% Betaproteobacteria), and Firmicutes with $11 \%$. Moreover, Nitrosomonadaceae represented less than $7 \%$ of Betaproteobacteria. Among less abundant phyla Deinococcus-Thermus (3\%), Actinobacteria (2.4\%) and Tenericutes (1.2\%) were mentioned. In a denitrification reactor, Proteobacteria dominated with almost $74 \%$, of which only $4.8 \%$ were Betaproteobacteria, Alfaproteobacteria represented as much as $78.3 \%$, and Gammaproteobacteria $17 \%$. Bacteroidetes was the second most abundant group with $16.1 \%$ of the total, while Actinobacteria were represented in only $1 \%$ of DNA sequences, and Firmicutes did not exceed even that.

\subsection{Simultaneous Ammonia Stripping Supporting Biological Ammonium Removal in a Single Reactor}

Ammonia stripping is a popular technological solution for high strength LFLs, because of its effectiveness. Cheung et al. [59] investigated the effectiveness of ammonia stripping at relatively low air flow rates, a low temperature and lime dosages of $10 \mathrm{~g} / \mathrm{L}$, as a pretreatment to remove N-TAN and COD load in LFL from two different landfills. After 1 day of aeration at $20^{\circ} \mathrm{C}$, the removal of N-TAN reached $70 \%$ to $90 \%$ depending on the aeration expenditure, but regardless of the origin of leachate. In contrast, COD were only reduced by lime precipitation, achieving $24 \%$ and $47 \%$ according to the age of the landfill. Authors stated that the most important factors affecting the efficiency of ammonia removal by stripping were leachate quality and the configuration of the reactor.

Generally, in LFL treating systems, ammonia stripping is proposed as a first stage pre-treatment before, e.g., biological stages. Smaou et al. [60] evaluated the performance of the 3-stage system based on air stripping, anaerobic digestion and aerobic-activated sludge post-treatment. Stripping of raw LFL characterized by $\mathrm{pH} 7.9$ and high loads of N-TAN $(2.8 \mathrm{~g} / \mathrm{L})$ resulted in an $80 \%$ reduction of N-TAN. High concentration organics (COD $30 \mathrm{~g} / \mathrm{L}$ ) with a relatively high $\mathrm{BOD}_{5} / \mathrm{COD}$ ratio of 0.3 allowed for the further batch anaerobic treatment of diluted LFL. As the authors reported after 80 days, the cumulative methane production was more than double after ammonia stripping.

There is a lack of data on the nitrogen removal efficiency in one-stage LFL biological treatment coupled with ammonia stripping. This technological solution is considered, e.g., in digesters processing bio-waste containing nitrogen-rich co-substrates. Fernandez-Gonzalez et al. [61] proposed to pair thermophilic reactors with an air-side stripping column operated $3 \mathrm{~h}, 3$ to 5 times a week, and treating $21 \%$ of the reactor volume in each batch, at $65{ }^{\circ} \mathrm{C}$ and without a $\mathrm{pH}$ control. In these conditions, the bacteria community, assessed by $16 \mathrm{~S}$ rRNA gene sequencing analysis, was mainly composed of Firmicutes, which on average represented $80.2 \%$ of biomass, followed by Bacteroidetes $(8.6 \%)$. The authors concluded that the bacterial community structure was not affected by periodical exposition to the harsh stripping conditions, including high temperature, $\mathrm{pH}$ and oxygen level, but were mainly shaped by such interrelated parameters as OLR, VFA and N-FAN.

Similarly, Yao et al. [62] studied the possibilities of an application of thermophilic daily manure anaerobic digestion with simultaneous N-FAN stripping within the same digester to simplify the system and to reduce operational costs of the process by overcoming ammonia inhibition occurring at 1.8-2.4 g N-TAN/L. Therefore the ammonia stripping strategy maintained N-TAN levels below $1.5 \mathrm{~g} / \mathrm{L}$, achieved with the optimum rate of airflow of $1 \mathrm{~L} / \mathrm{min}$, which significantly enhanced the microbial activity, and allowed it to reach a 2.3-fold higher cumulative methane production than in the control.

Roughly speaking, the metabolic pathways of nitrogen conversion demand oxygen or oxides as an electron acceptors, it is therefore obvious that the aeration strategy has a key role in the effective functioning of biological treatment systems, especially when ammonia prevails in wastewater. Most of 
the processes utilized for nitrogen removal engage in the complex bacterial community, and a range of conditions, from oxygen-rich to anaerobic, are demanded depending on the specific requirements of microorganisms and the role they play. Therefore, to maintain a relevant DO concentration, the aeration strategy should include such issues as, for example, the method of air delivery, compartmentation of the reactor into aeration and mixing zones, or the definition of the time of aeration in sequential batch reactors, etc. From an economical point of view, on the technical scale, aeration must be considered also as the most cost-intensive process, consuming up to $90 \%$ of the energy used by the plant $[63,64]$. Therefore, on the one hand, more effective methods of air supply are considered, on the other, biological processes that consume less oxygen are, especially when ammonia removal is the main purpose of treatment, not organics $[49,54,55]$. However, anaerobic conditions make it difficult to strip the surplus nitrogen to the atmosphere.

Although significant removal of $\mathrm{N}-\mathrm{NH}_{4}$ was observed in both HSBRs, and a thesis of biological nature of this process is supported by observed differential growth of microbial biomass, it must be also taken into consideration that the ammonia in water solutions has an equilibrium point $\mathrm{pKa}=9.25$ at $25^{\circ} \mathrm{C}$, which meets characteristics of LFL used in the experiment. In such conditions, a significant part of the nitrogen is out of reach of biological conversion. Moreover, a higher concentration of N-FAN may inhibit microbiological activity, decreasing the removal efficiency of the remaining $\mathrm{N}_{-} \mathrm{NH}_{4}$. A slight increase of $\mathrm{pH}$ observed during the experiment theoretically allowed the conversion of over half of N-TAN to N-FAN form, but $\mathrm{H}^{+}$concentration still did not inhibit biological activity of nitrificators. The nitrification process increases $\mathrm{H}_{2} \mathrm{CO}_{3}$ and decreases $\mathrm{HCO}_{3}$ levels, thus the $\mathrm{pH}$ would tend to be reduced. However, this effect is mediated by $\mathrm{CO}_{2}$ stripping, therefore finally the $\mathrm{pH}$ is raised by aeration. The literature data shows that significant amounts of $\mathrm{CO}_{2}$ could be stripped in biological reactors, however, models describing this process could be more complicated than in the case of N-FAN [65]. The increase of $\mathrm{pH}$ in biological reactors could be also explained by other mechanisms, such as assimilatory sulfate reduction in sulfur-rich LFL. Anthonisen [21] explains that the nitrification is less affected at $\mathrm{pH}$ values between 8 and 9 because of the ability of N-FAN and free nitrous acid to penetrate cell membranes of the nitrifying organisms. When the $\mathrm{pH}$ inside the cell is lower than the $\mathrm{pH}$ outside, N-FAN penetrates the membrane and inhibits the bacteria activity, whilst $\mathrm{N}_{-} \mathrm{NH}_{4}$ remains in the environment outside the cell. If $\mathrm{pH}$ inside the cell is higher than outside, the N-FNA penetrates the cell, rather than $\mathrm{N}-\mathrm{NO}_{2}$.

High levels of N-FAN does not imply yet high efficiency of the technical process of stripping. To achieve direct transition of N-FAN to the atmosphere in gaseous form, such parameters must jointly be provided as high $\mathrm{pH}(>11)$, high temperature and highly developed surface of liquid-gas contact [20], which were mostly not fulfilled in this experiment, whilst aeration was limited to maintain DO level $\leq 1 \mathrm{mg} \mathrm{O}_{2} / \mathrm{L}$. As the results show, the method of air delivery to reactors determines the difference in the effectiveness of N-TAN removal. The biological process, under conditions of limited access to oxygen, could have an impact on $\mathrm{pH}$, and consequently increase the susceptibility of nitrogen for removal by stripping, which reduces the concentration of N-FAN and enhances microbial activity. In R2, where the biomass and number of bacterial DNA copies was lower, N-FAN accumulation occurred, and both processes were ineffective.

Considering the biological part of nitrogen removal, it can be stated that $\mathrm{N}_{-} \mathrm{NH}_{4}$ was removed with relatively high efficiency in top-aerated SBR, which was obtained in a relatively short time, in conditions of high concentration of N-FAN, carbon-nitrogen imbalance and low carbon bioavailability. Such conditions are preferred by AOB and favor them over the NOB, therefore are often proposed as a method through which the nitrite pathway is achieved, when most of the $\mathrm{N}^{-\mathrm{NH}_{4}}$ can be converted into $\mathrm{N}-\mathrm{NO}_{2}$, and then to gaseous $\mathrm{N}_{2}$ by autotrophic anaerobic ammonium oxidizers (AnAOB) or anaerobic denitrifiters. Several processes may be considered as the model fitted with obtained data $[44,66]$. However, such parameters of treatment as: hydraulic retention time, temperature, $\mathrm{C} / \mathrm{N}$ ratio and above all, no accumulation of $\mathrm{N}-\mathrm{NO}_{2}$ and $\mathrm{N}-\mathrm{NO}_{3}$ observed during the diurnal analysis of nitrogen removal kinetics (Figure 4) allows us to state that simultaneous nitrification and denitrification would be the 
most likely process responsible for the biological part of ammonium removal. The occurrence of SND without the external carbon source is possible due to accumulation of organic compounds in the deeper layers of biomass carriers [67]. The autotrophic nitrifiers grows more slowly than heterotrophic bacteria, therefore SND requires a carbon source to reduce the rate of heterotrophic nitrification and denitrification [47]. Autotrophic and heterotrophic microorganisms can compete when OLR is high. In SBR, the competition for oxygen between heterotrophic and autortrophic bacteria occurs at OLR higher than $2 \mathrm{~kg} / \mathrm{m}^{3}$.day [4]. At $30{ }^{\circ} \mathrm{C}$, the $\mathrm{COD} / \mathrm{N}$ ratio should be at least 10 , lower values like 7.5 achieved in this experiment, may result in a rapid reduction of the available carbon and disrupt the process [68]. However, the application of biomass carriers results in the development of the microbial community structure, and helps increase the mass of organic compounds [60], thus the ratio should not always be a key parameter for SND.

In the SND process, the most common bacteria responsible for the two step conversion are the autotrophic organisms, like Nitrosomonas or Nitrobacter, and varied heterotrophs. The former obtain energy from the oxidation of ammonia and carbon from $\mathrm{CO}_{2}$, and use oxygen as the electron acceptor. The heterotrophs are responsible for denitrification and the reduction of nitrates prefer low levels of DO. SND accommodates autotrophs and heterotrophs in one reactor with controlled DO levels, by developing an oxygen gradient. Technically this can be done in two approaches, one by adding the source of oxygen in one isolated location of the reactor-when DO concentration decreases with distance, nitrifiers gives the way to the heterotrophs to complete the nitrogen removal. The other method is to produce the floc of activated sludge wherein DO concentration drops in deeper layers. In the proposed construction of the hybrid reactor, these two methods are combined; oxygen is supplied from above, and the structure of biomass carriers supports the creation of the DO gradient. A selection of material used as a biomass carrier has a key importance; previous experiences in the application of different biomass carriers turned our attention to reticulated polymeric foams, characterized by porous but repetitive structures with a highly developed extended surface. These materials used as a filling in hybrid sequential reactors prevent biomass washout and create suitable conditions for simultaneous growth of aerobic and anaerobic microorganisms [22].

Moreover, the operational costs of the proposed design, including energy consumption, should be considered. A shortened migration distance of air bubbles in shallow-aerated SBR means a shorter time of contact between the gas and liquid phases, which was discussed, e.g., in the example of a semi-technical scale system with activated sludge mixed by aeration [69]. Thus, seemingly lower energy expenditure for low pressure aeration is combined with reduced efficiency of mass transfer, and must be compensated by a larger volume of injected air or intense mixing to maintain DO level. In this work, air inlet arrangement also implied the differences in hydrodynamics between the reactors; in R2 mass transport was forced mainly with air bubbles, therefore fluid flowed from the inside channel upward and downward along the side walls, when in R1 mass transport was supported by stirrer generating an upward flow along the side walls, as in standard axially mixed reactors [70] (the directions are suggested by arrows on Figure 1). The relatively high effect of stripping achieved in this experiment may be also related to the high foaming power of LFL. Foaming is usually considered a negative side effect in WWTP. However, the foam structure allows one of the most efficient gas-liquid mass transfer [71], although the excessive foam must be effectively broken.

\section{Conclusions}

Biological sequential batch reactors are often operated in landfills as a low cost and environmental friendly technological solution alternative to physicochemical processes, especially when high loads of N-TAN are considered. However, most LFLs are characterized by temporal variability of chemical composition, including $\mathrm{pH}$. In some of landfills, $\mathrm{pH}$ of LFL exceeds a value of 9.0, inducing N-FAN formation. Simple modification of HSBR aeration, proposed by the authors, partially removed N-FAN by simultaneous stripping in a single reactor, avoiding its accumulation, and helping to overcome 
inhibition of bacterial growth. Application of HSBRs filled with reticulated open-pore polymer foam with a highly developed surface area, enhanced the SND process to remove remaining $\mathrm{N}-\mathrm{NH}_{4}$.

Despite the removal of N-TAN not being complete, the economics of the process in a technical scale must be considered taking into account, inter alia, unit costs of physical stripping or the complications with controlling $\mathrm{pH}$ in a biological stage. The proposed system can be also used as a low-cost element of the multi-stage installation.

Author Contributions: Ł.J. and J.K.-J. have contributed in developing the research ideas, conducting the research, analyzing the data, and writing the manuscript; A.M. has contributed to writing the manuscript; all authors provided efforts on research, lab analysis, read and approved the final manuscript. All authors have read and agreed to the published version of the manuscript.

Funding: The project was supported by the Minister of Science and Higher Education of Poland (Project No. 026/RID/2018/19 “Regional Initiative of Excellence", 2019-2022).

Conflicts of Interest: The authors declare no conflict of interest.

\section{Abbreviations}

\begin{tabular}{|c|c|}
\hline AnAOB & anaerobic ammonium oxidizers \\
\hline $\mathrm{AOB}$ & ammonia-oxidizing bacteria \\
\hline $\mathrm{BOD}_{5}$ & biological oxygen demand in five days \\
\hline COD & chemical oxygen demand \\
\hline DGGE & denaturing gradient electrophoresis \\
\hline $\mathrm{DO}$ & dissolved oxygen \\
\hline HRT & hydraulic retention time \\
\hline HS & humic substances \\
\hline HSBR & hybrid sequencing batch reactor \\
\hline LFL & landfill leachate \\
\hline M-W & Mann-Whitney-Wlicoxon statistics \\
\hline MLSS & mixed liquor suspended solids \\
\hline N-FAN & free ammonium nitrogen \\
\hline $\mathrm{N}-\mathrm{N}_{\mathrm{K}}$ & Kjeldahl nitrogen \\
\hline $\mathrm{N}-\mathrm{N}_{\text {org }}$ & organic nitrogen \\
\hline $\mathrm{N}-\mathrm{NH}_{4}$ & ammonia nitrogen \\
\hline N-FNA & free nitrous acid \\
\hline $\mathrm{N}-\mathrm{NO}_{2}$ & nitrite nitrogen \\
\hline $\mathrm{N}-\mathrm{NO}_{3}$ & nitrate nitrogen \\
\hline N-TAN & total ammonia nitrogen \\
\hline NGC & new generation sequencing \\
\hline NLR & nitrogen loading rate \\
\hline NOB & nitrite-oxidizing bacteria \\
\hline OLR & organic loading rate \\
\hline PCR & polymerase chain reaction \\
\hline PN & part nitrification \\
\hline PU & polyurethane \\
\hline qPCR & quantitative polymerase chain reaction \\
\hline SND & simultaneous nitrification and denitrification \\
\hline SSCP & single-strand conformation polymorphism \\
\hline TGGE & temperature gradient electrophoresis \\
\hline TSS & total suspended solids \\
\hline VFA & volatile facid acid \\
\hline VSS & volatile suspended solids \\
\hline
\end{tabular}

\section{References}

1. Cossu, R. Technical evolution of landfilling. Waste Manag. 2010, 30, 947-948. [CrossRef] [PubMed]

2. Zhang, Q.-Q.; Tian, B.-H.; Zhang, X.; Ghulam, A.; Fang, C.-R.; He, R. Investigation on characteristics of leachate and concentrated leachate in three landfill leachate treatment plants. Waste Manag. 2013, 33, 2277-2286. [CrossRef] [PubMed] 
3. Jurczyk, Ł.; Koc-Jurczyk, J. Quantitative dynamics of ammonia-oxidizers during biological stabilization of municipal landfill leachate pretreated by Fenton's reagent at neutral pH. Waste Manag. 2017, 63, 310-326. [CrossRef] [PubMed]

4. Guo, J.; Zhang, L.; Chen, W.; Ma, F.; Liu, H.; Tian, Y. The regulation and control strategies of a sequencing batch reactor for simultaneous nitrification and denitrification at different temperatures. Bioresour. Technol. 2013, 133, 59-67. [CrossRef] [PubMed]

5. Guin, J.P.; Bhardwaj, Y.; Varshney, L. Efficient degradation of butylparaben by gamma radiolysis. Appl. Radiat. Isot. 2017, 122, 21-27. [CrossRef] [PubMed]

6. Moreira, F.C.; Soler, J.; Fonseca, A.; Saraiva, I.; Boaventura, R.A.R.; Brillas, E.; Vilar, V.J. Electrochemical advanced oxidation processes for sanitary landfill leachate remediation: Evaluation of operational variables. Appl. Catal. B Environ. 2016, 182, 161-171. [CrossRef]

7. Gong, Y.; Wang, S.; Xu, H.; Guo, Y.; Tang, X. Partial oxidation of landfill leachate in supercritical water: Optimization by response surface methodology. Waste Manag. 2015, 43, 343-352. [CrossRef]

8. Oloibiri, V.; Ufomba, I.; Chys, M.; Audenaert, W.T.; Demeestere, K.; Van Hulle, S.W. A comparative study on the efficiency of ozonation and coagulation-flocculation as pretreatment to activated carbon adsorption of biologically stabilized landfill leachate. Waste Manag. 2015, 43, 335-342. [CrossRef]

9. Ferraz, F.; Povinelli, J.; Vieira, E.M. Ammonia removal from landfill leachate by air stripping and absorption. Environ. Technol. 2013, 34, 2317-2326. [CrossRef]

10. Kurniawan, T.; Lo, W.; Chan, G.Y.S. Physico-chemical treatments for removal of recalcitrant contaminants from landfill leachate. J. Hazard. Mater. 2006, 129, 80-100. [CrossRef]

11. Müller, G.T.; Giacobbo, A.; Chiaramonte, E.A.D.S.; Rodrigues, M.; Meneguzzi, Á.; Bernardes, A.M. The effect of sanitary landfill leachate aging on the biological treatment and assessment of photoelectrooxidation as a pre-treatment process. Waste Manag. 2015, 36, 177-183. [CrossRef]

12. Peng, Y.; Zhang, L.; Zeng, W.; Zheng, S.; Mino, T.; Satoh, H. Organic removal by denitritation and methanogenesis and nitrogen removal by nitritation from landfill leachate. Water Res. 2008, 42, 883-892. [CrossRef] [PubMed]

13. Slack, R.J.; Gronow, J.; Voulvoulis, N. Household hazardous waste in municipal landfills: Contaminants in leachate. Sci. Total. Environ. 2005, 337, 119-137. [CrossRef] [PubMed]

14. El-Fadel, M.; Bou-Zeid, E.; Chahine, W.; Alayli, B. Temporal variation of leachate quality from pre-sorted and baled municipal solid waste with high organic and moisture content. Waste Manag. 2002, 22, 269-282. [CrossRef]

15. Jetten, M.; Horn, S.J.; Van Loosdrecht, M.C.M. Towards a more sustainable municipal wastewater treatment system. Water Sci. Technol. 1997, 35, 171-180. [CrossRef]

16. Schmidt, I.; Sliekers, O.; Schmid, M.; Bock, E.; Fuerst, J.A.; Kuenen, J.G.; Jetten, M.S.M.; Strous, M. New concepts of microbial treatment processes for the nitrogen removal in wastewater. FEMS Microbiol. Rev. 2003, 27, 481-492. [CrossRef]

17. Kadam, P.C.; Boone, D.R. Influence of $\mathrm{pH}$ on Ammonia Accumulation and Toxicity in Halophilic, Methylotrophic Methanogens. Appl. Environ. Microbiol. 1996, 62, 4486-4492. [CrossRef]

18. Liu, Y.; Ngo, H.H.; Guo, W.; Peng, L.; Wang, D.; Ni, B.-J. The roles of free ammonia (FA) in biological wastewater treatment processes: A review. Environ. Int. 2019, 123, 10-19. [CrossRef]

19. Kinidi, L.; Tan, I.A.W.; Wahab, N.B.A.; Bin Tamrin, K.F.; Hipolito, C.N.; Salleh, S.F. Recent Development in Ammonia Stripping Process for Industrial Wastewater Treatment. Int. J. Chem. Eng. 2018, 2018, 1-14. [CrossRef]

20. Huang, J.-C.; Shang, C. Air Stripping. In Advanced Physicochemical Treatment Processes; Springer Science and Business Media LLC: Berlin, Germnay, 2006; pp. 47-79.

21. Anthonisen, A.C.; Loehr, R.C.; Prakasam, T.B.; Srinath, E.G. Inhibition of nitrification by ammonia and nitrous acid. J. Water Pollut. Control. Fed. 1976, 48, 835-852.

22. Koc-Jurczyk, J.; Jurczyk, Ł. Biological Treatment of Landfill Leachate at Elevated Temperature in the Presence of Polyurethane Foam of Various Porosity. CLEAN-Soil Air Water 2016, 45, 1500264. [CrossRef]

23. Schneider, C.A.; Rasband, W.S.; Eliceiri, K.W. NIH Image to ImageJ: 25 years of image analysis. Nat. Methods 2012, 9, 671-675. [CrossRef] [PubMed] 
24. Xu, Z.-Y.; Zeng, G.-M.; Yang, Z.; Xiao, Y.; Cao, M.; Sun, H.-S.; Ji, L.-L.; Chen, Y. Biological treatment of landfill leachate with the integration of partial nitrification, anaerobic ammonium oxidation and heterotrophic denitrification. Bioresour. Technol. 2010, 101, 79-86. [CrossRef]

25. Klimiuk, E.; Lossow, K.; Bulińska, M. Kinetyka Reakcji i Modelowanie Reaktorów Biochemicznych w Procesach Oczyszczania Ścieków; ART: Olsztyn, Poland, 1995.

26. PN/90/C-04540.01. Water and Wastewater-Research $p H$, Acidity and Alkalinity_Determination of $p H$ of Water and Wastewater for Electrolytic Conductivity of 10 microsiemens / cm and above Electrometric Method; Polish Committee for Standardization: Warsaw, Poland, 1990.

27. PN-EN 27888:1999. Water Quality-Determination of the Electrical Conductivity; Polish Committee for Standardization: Warsaw, Poland, 1999.

28. PN-ISO 6060:2006. Water Quality-Determination of Chemical Oxygen Demand; Polish Committee for Standardization: Warsaw, Poland, 2006.

29. DIN EN 1899-1/EN 1899-2. Determination of Biochemical Oxygen Demand after $n$ Days (BODn); DIN Standards Committee Textiles and Textile Machinery: Berlin, Germany, 1998.

30. PN-EN 25663:2001. Water Quality-Determination of Kjeldahl Nitrogen-Method after Mineralization with Selenium; Polish Committee for Standardization: Warsaw, Poland, 2001.

31. PN-ISO 5664:2002. Water Quality—Determination of Ammonium Nitrogen-Method Distillation Titration; Polish Committee for Standardization: Warsaw, Poland, 2002.

32. EN 26777/1993. Water Quality—Determination of Nitrite-Molecular Adsorption Spectrometric Method; Polish Committee for Standardization: Warsaw, Poland, 1993.

33. PN-82/C-04576/08. Water and Wastewater-Tests for Nitrogen Compounds-Determination of Nitric Colorimetric Method; Polish Committee for Standardization: Warsaw, Poland, 1982.

34. Xie, B.; Xiong, S.; Liang, S.; Hu, C.; Zhang, Z.; Lu, J. Performance and bacterial compositions of aged refuse reactors treating mature landfill leachate. Bioresour. Technol. 2012, 103, 71-77. [CrossRef] [PubMed]

35. Xie, Z.; Wang, Z.; Wang, Q.; Zhu, C.; Wu, Z. An anaerobic dynamic membrane bioreactor (AnDMBR) for landfill leachate treatment: Performance and microbial community identification. Bioresour. Technol. 2014, 161, 29-39. [CrossRef] [PubMed]

36. Xie, B.; Lv, Z.; Hu, C.; Yang, X.; Li, X. Nitrogen removal through different pathways in an aged refuse bioreactor treating mature landfill leachate. Appl. Microbiol. Biotechnol. 2012, 97, 9225-9234. [CrossRef]

37. Silva, T.F.; Vieira, E.; Lopes, A.R.; Nunes, O.C.; Fonseca, A.; Saraiva, I.; Boaventura, R.A.; Vilar, V.J. How the performance of a biological pre-oxidation step can affect a downstream photo-Fenton process on the remediation of mature landfill leachates: Assessment of kinetic parameters and characterization of the bacterial communities. Sep. Purif. Technol. 2017, 175, 274-286. [CrossRef]

38. De Gregoris, T.B.; Aldred, N.; Clare, A.S.; Burgess, J.G. Improvement of phylum- and class-specific primers for real-time PCR quantification of bacterial taxa. J. Microbiol. Methods 2011, 86, 351-356. [CrossRef]

39. Yang, Y.-W.; Chen, M.-K.; Yang, B.-Y.; Huang, X.-J.; Zhang, X.-R.; He, L.-Q.; Zhang, J.; Hua, Z.-C. Use of $16 S$ rRNA Gene-Targeted Group-Specific Primers for Real-Time PCR Analysis of Predominant Bacteria in Mouse Feces. Appl. Environ. Microbiol. 2015, 81, 6749-6756. [CrossRef]

40. Ni, B.-J.; Ruscalleda, M.; Smets, B. Evaluation on the microbial interactions of anaerobic ammonium oxidizers and heterotrophs in Anammox biofilm. Water Res. 2012, 46, 4645-4652. [CrossRef]

41. Gel Analyzer 2010. Freeware 1D Gel Electrophoresis Image Analysis Software. Available online: http: //www.gelanalyzer.com (accessed on 5 May 2012).

42. Sun, W.; Yue, D.; Song, J.; Nie, Y. Adsorption removal of refractory organic matter in bio-treated municipal solid waste landfill leachate by anion exchange resins. Waste Manag. 2018, 81, 61-70. [CrossRef] [PubMed]

43. Yang, Y.; Zhang, L.; Han, X.; Zhang, S.; Li, B.; Peng, Y. Determine the operational boundary of a pilot-scale single-stage partial nitritation/anammox system with granular sludge. Water Sci. Technol. 2016, 73, 2085-2092. [CrossRef]

44. Akgul, D.; Aktan, C.K.; Yapsakli, K.; Mertoglu, B. Treatment of landfill leachate using UASB-MBR-SHARON-Anammox configuration. Biodegradation 2012, 24, 399-412. [CrossRef]

45. Yusof, N.; Hassan, M.; Phang, L.; Tabatabaei, M.; Othman, M.R.; Mori, M.; Wakisaka, M.; Sakai, K.; Shirai, Y. Nitrification of ammonium-rich sanitary landfill leachate. Waste Manag. 2010, 30, 100-109. [CrossRef] [PubMed]

46. Rhodes, P.C. Particle Technology, 2nd ed.; John Wiley \& Sons: Chippenham, UK, 2008. 
47. Van Dongen, U.; Jetten, M.S.M.; Van Loosdrecht, M.C.M. The SHARON ${ }^{\circledR}$-Anammox ${ }^{\circledR}$ process for treatment of ammonium rich wastewater. Water Sci. Technol. 2001, 44, 153-160. [CrossRef] [PubMed]

48. Wang, X.; Han, J.; Chen, Z.; Jian, L.; Gu, X.; Lin, C.-J. Combined processes of two-stage Fenton-biological anaerobic filter-biological aerated filter for advanced treatment of landfill leachate. Waste Manag. 2012, 32, 2401-2405. [CrossRef] [PubMed]

49. Gu, S.; Wang, S.; Yang, Q.; Yang, P.; Peng, Y. Startup partial nitrification at low temperature with a real-time control strategy based on blower frequency and pH. Bioresour. Technol. 2012, 112, 34-41. [CrossRef]

50. Ramaswami, S.; Behrendt, J.; Kalyanasundaram, S.; Eggers, S.; Otterpohl, R. Experiences from an investigation on the potential of packed bed reactors for high rate nitrification of mature landfill leachates. J. Water Process. Eng. 2018, 22, 59-65. [CrossRef]

51. Dechesne, A.; Musovic, S.; Palomo, A.; Diwan, V.; Smets, B. Underestimation of ammonia-oxidizing bacteria abundance by amplification bias in amoA-targeted qPCR. Microb. Biotechnol. 2016, 9, 519-524. [CrossRef]

52. Peng, F.; Gao, Y.; Zhu, X.; Pang, Q.; Wang, L.; Xu, W.; Yu, J.; Gao, P.; Huang, J.; Cui, Y. Removal of High-Strength Ammonia Nitrogen in Biofilters: Nitrifying Bacterial Community Compositions and Their Effects on Nitrogen Transformation. Water 2020, 12, 712. [CrossRef]

53. Díaz, A.I.; Oulego, P.; Laca, A.; González, J.M.; Díaz, M. Metagenomic Analysis of Bacterial Communities from a Nitrification-Denitrification Treatment of Landfill Leachates. CLEAN—Soil Air Water 2019, 47. [CrossRef]

54. Fudala-Ksiazek, S.; Łuczkiewicz, A.; Fitobór, K.; Olańczuk-Neyman, K. Nitrogen removal via the nitrite pathway during wastewater co-treatment with ammonia-rich landfill leachates in a sequencing batch reactor. Environ. Sci. Pollut. Res. 2014, 21, 7307-7318. [CrossRef] [PubMed]

55. Wei, D.; Du, B.; Xue, X.; Dai, P.; Zhang, J. Analysis of factors affecting the performance of partial nitrification in a sequencing batch reactor. Appl. Microbiol. Biotechnol. 2014, 98, 1863-1870. [CrossRef] [PubMed]

56. Wang, L.-K.; Zeng, G.; Yang, Z.-H.; Luo, L.-L.; Xu, H.-Y.; Huang, J. Operation of partial nitrification to nitrite of landfill leachate and its performance with respect to different oxygen conditions. Biochem. Eng. J. 2014, 87, 62-68. [CrossRef]

57. Liang, Z.; Liu, J.-X.; Li, J. Decomposition and mineralization of aquatic humic substances (AHS) in treating landfill leachate using the Anammox process. Chemosphere 2009, 74, 1315-1320. [CrossRef]

58. Gabarró, J.; Amo, E.H.-D.; Gich, F.; Ruscalleda, M.; Balaguer, M.D.; Colprim, J. Nitrous oxide reduction genetic potential from the microbial community of an intermittently aerated partial nitritation SBR treating mature landfill leachate. Water Res. 2013, 47, 7066-7077. [CrossRef]

59. Cheung, K.C.; Chu, L.M.; Wong, M.H. Ammonia stripping as a pretreatment for landfill leachate. Water Air Soil Pollut. 1997, 94, 209-221. [CrossRef]

60. Smaoui, Y.; Bouzid, J.; Sayadi, S. Combination of air stripping and biological processes for landfill leachate treatment. Environ. Eng. Res. 2019, 25, 80-87. [CrossRef]

61. Gonzalez, N.F.; Pedizzi, C.; Lema, J.M.; Carballa, M. Air-side ammonia stripping coupled to anaerobic digestion indirectly impacts anaerobic microbiome. Microb. Biotechnol. 2019, 12, 1403-1416. [CrossRef]

62. Yao, Y.; Yu, L.; Ghogare, R.; Dunsmoor, A.; Davaritouchaee, M.; Chen, S. Simultaneous ammonia stripping and anaerobic digestion for efficient thermophilic conversion of dairy manure at high solids concentration. Energy 2017, 141, 179-188. [CrossRef]

63. Drewnowski, J.; Remiszewska-Skwarek, A.; Duda, S.; Łagód, G. Aeration Process in Bioreactors as the Main Energy Consumer in a Wastewater Treatment Plant. Review of Solutions and Methods of Process Optimization. Processes 2019, 7, 311. [CrossRef]

64. Fernandez-Álvarez, G.; Pérez, J.I.P.; Gómez, M. Optimization of Reactor Depth in Membrane Bioreactors for Municipal Wastewater Treatment. J. Environ. Eng. 2014, 140, 04014019. [CrossRef]

65. Matsunaga, N.; Kano, K.; Maki, Y.; Dobashi, T. Estimation of dissolved carbon dioxide stripping in a large bioreactor using model medium. J. Biosci. Bioeng. 2009, 107, 419-424. [CrossRef] [PubMed]

66. Hellinga, C.; Schellen, A.A.J.C.; Mulder, J.W.; van Loosdrecht, M.C.M.; Heijnen, J.J. The SHARON Process: An Innovative Method for Nitrogen Removal From Ammonium-Rich Waste Water. Water Sci. Technol. 1998, 37, 135-142. [CrossRef]

67. Lim, J.-W.; Seng, C.-E.; Lim, P.-E.; Ng, S.-L.; Sujari, A.-N.A. Nitrogen removal in moving bed sequencing batch reactor using polyurethane foam cubes of various sizes as carrier materials. Bioresour. Technol. 2011, 102, 9876-9883. [CrossRef]

68. Mulder, J.W.; van Kempen, R. N-removal by SHARON. Water Qual. Int. 1997, 2, 30-31. 
69. Al-Ahmady, K.K. Analysis of Oxygen Transfer Performance on Sub-surface Aeration Systems. Int. J. Environ. Res. Public Health 2006, 3, 301-308. [CrossRef]

70. Bakker, A.; Van den Akker, H.E.A. Gas-Liquid Contacting with Axial Flow Impellers. Chem. Eng. Res. Design 1994, 72, 573-582.

71. Stevenson, P. Gas-Liquid Mass Transfer in Foam. In Foam Engineering: Fundamentals and Applications, 1st ed.; Stevenson, A., Ed.; John Wiley \& Sons, Ltd.: Hoboken, NJ, USA, 2012; pp. 331-353. ISBN 9781119954620.

(C) 2020 by the authors. Licensee MDPI, Basel, Switzerland. This article is an open access article distributed under the terms and conditions of the Creative Commons Attribution (CC BY) license (http://creativecommons.org/licenses/by/4.0/). 